\title{
Site-specific phosphorylation regulates the functions of kindlin-3 in a variety of cells
}

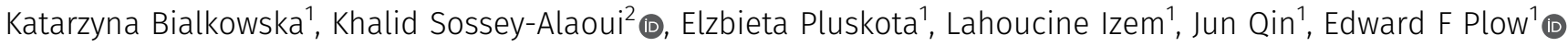

\begin{abstract}
Studies of isolated cells, mice, and humans have demonstrated the vital role of the FERM domain protein kindlin-3 in integrin activation in certain hematopoietic and non-hematopoietic cells, consequent to binding to integrin $\beta$-subunits. To explore regulatory mechanisms, we developed a monoclonal antibody that selectively recognizes the phosphorylated form of $\mathrm{Ser}^{484}\left(\mathrm{ps}^{484}\right)$ in kindlin-3. Activation of platelets, HEL megakaryocytic-like cells and BT549 breast cancer cells led to enhanced expression of $\mathrm{ps}^{484}$ as assessed by immunofluorescence or Western blotting. In platelets, $\mathrm{p}^{484}$ rose rapidly and transiently upon stimulation. When a mutant form of kindlin-3, $\mathrm{T}^{482} \mathrm{~S}^{484} / \mathrm{AA}$ kindlin-3, was transduced into mouse megakaryocytes, it failed to support activation of integrin $\alpha_{11 \mathrm{~b}} \beta_{3}$, whereas wild-type kindlin-3 did. In MDA-MB231 breast cancer cells, expression of $\mathrm{T}^{482} \mathrm{~S}^{484} / \mathrm{AA}$ kindlin-3 suppressed cell spreading, migration, invasion, and VEGF production. Wild-type kindlin-3 expressing cells markedly increased tumor growth in vivo, whereas $\mathrm{T}^{482} \mathrm{~S}^{484} / \mathrm{AA}$ kindlin-3 significantly blunted tumor progression. Thus, our data establish that a unique phosphorylation event in kindlin-3 regulates its cellular functions.
\end{abstract}

DOI 10.26508/lsa.201900594 | Received 30 October 2019 | Revised 22 January 2020 | Accepted 23 January 2020 | Published online 5 February 2020

\section{Introduction}

The major functions of integrin adhesion receptors, ligand binding and subsequent intracellular signaling, are tightly regulated, especially for the integrins expressed on blood cells, which are exposed to a variety of circulating ligands. The integrins on these cell surfaces exist in a resting state, which preclude them from binding their ligands with high avidity/affinity. However, when cells are exposed to a stimulatory agonist, the integrins rapidly convert to active conformation, which supports robust ligand binding (Marguerie et al, 1979; Qin et al, 2004; Ma et al, 2007; Sun et al, 2019). Engagement of binding partners by the integrin cytoplasmic tails (CTs) regulates integrin activation; these binding partners induce inside-out signals that perturb the integrin transmembrane domains and then regulates the ligand binding site within extracellular region of integrin. Ligand binding can, in turn, induce outside-in signals that result in multiple cellular responses.

The kindlin family of intracellular proteins have been shown to regulate bidirectional integrin signaling. Kindlins are present in integrin-containing adhesion sites and provide a link between integrin-induced signaling and the actin cytoskeleton (Tu et al, 2003; Ussar et al, 2006; Shi et al, 2007). Three kindlin family members are present in mammals; each kindlin consists of a FERM ( $F$ for 4.1 protein, $E$ for ezrin, $\mathrm{R}$ for radixin and $M$ for moesin) domain with an inserted pleckstrin homology domain. When compared with other FERM domains, the FERM domain of kindlins shows closest homology to that of talin, another protein engaged in integrininduced signaling (Calderwood et al, 1999; Vinogradova et al, 2002; Garcia-Alvarez et al, 2003; Tadokoro et al, 2003; Klapholz \& Brown, 2017; Gough \& Goult, 2018; Sun et al, 2019). Kindlins and talin act in cooperation to optimize integrin activation, by binding to integrin cytoplasmic tails, and this interaction involves their F3 (PTB) subdomains within their FERM domains (Shi et al, 2007; Ma et al, 2008; Montanez et al, 2008). Hence, cells or mice with decreased kindlin expression levels fail to activate their integrins properly. Kindlin-1 is expressed predominantly in epithelial cells; mutation of kindlin-1 in humans manifests as Kindler syndrome, a rare disease characterized by skin blistering and poikiloderma with frequent intestinal complications (Jobard et al, 2003; Siegel et al, 2003). Kindlin-2 is expressed in variety of tissues and cell types; kindlin-2 knockout in mice and zebrafish is lethal early in embryonic development (Dowling et al, 2008; Montanez et al, 2008). Postnatal loss of kindlin-2 in cardiomyocytes leads to progressive heart failure (Zhang et al, 2016). Kindlin-3-null mice show pronounced defects in platelet and leukocyte integrin-dependent functions, and kindlin3-null mice die on day 7 postnatally (Moser et al, 2008). Humans with kindlin-3 mutations or deficiency exhibit rare syndrome referred to as LADIII. LADIII syndrome is a consequence of an inability of the cells to activate $\beta_{1}, \beta_{2}$, and $\beta_{3}$ integrins, with manifestations that include susceptibility to infections, episodic bleeding, and osteopetrosis. Abnormal red blood cell shapes were also observed in some patients with LADIII (Kuijpers et al, 2009; Malinin et al, 2009; Svensson et al, 2009; Meller et al, 2012). Kindlin-3 has been shown to be present and functional in endothelial cells (Bialkowska et al,

${ }^{1}$ Department of Cardiovascular and Metabolic Sciences, Lerner Research Institute Cleveland Clinic, Cleveland, OH, USA ${ }^{2}$ Department of Molecular Medicine, School of Medicine, Case Western Reserve University, Cleveland, OH, USA

Correspondence: plowe@ccf.org 
2010) and it acts as a tumor promoter in breast cancer (BC) cells (Sossey-Alaoui et al, 2014). Despite the large body of evidence that emphasize the role of kindlin-3 in integrin-induced signaling in many different cell types, the mechanisms of kindlin-3 induced integrin activation are not well understood. One well established binding site in kindlin-3 is present in its F3 domain; this integrinbinding site is located at kindlin-3 $Q^{597} / W^{598}$. Unlike kindlin-3 knockout mice, mice in which QW have been mutated to alanines (kindlin-3 QW/AA) are viable for at least 6 mo, although they bleed excessively upon tail resection and have prolonged arterial occlusion times upon vascular injury (Xu et al, 2014).

Because the activation of integrins on blood cells requires strict regulation, it would seem that involvement of kindlin-3 could be a checkpoint in the activation process. We first considered whether talin, which is known to undergo unmasking to bind in integrin (Goksoy et al, 2008), might regulate kindlin binding to the $\beta 3 \mathrm{CT}$, but their interaction with the CT seemed to be independent (Bledzka et al, 2012) and might require a bridging protein (Gao et al, 2017; Klapproth et al, 2019). We then considered whether a posttranslational modification(s) could regulate kindlin-3 function. Indeed, in a prior study, we used mass spectrometry to show that phosphorylation of kindlin-3 occurs in platelets upon agonist stimulation in a region that is not conserved in the other two kindlin family members (Bialkowska et al, 2015). To determine whether this phosphorylation event is significant in kindlin-3 required the development of new reagents and approaches. We are now able to convincingly show that phosphorylation of kindlin-3 at $\mathrm{S}^{484}$ is regulated by agonists and occurs rapidly upon cell stimulation and that this posttranslational modification controls key functions of kindlin-3 in both hematopoietic and non-hematopoietic cells.

In a previous work, we have examined the relationship between kindlin-3 and BC in mouse models and human tissues (Sossey-Alaoui et al, 2014). Kindlin-3 overexpression in a BC cell line increased primary tumor growth and lung metastasis and mechanistically, kindlin-3overexpressing cells displayed a marked increase in VEGF secretion, which was dependent upon enhanced expression of the Twist transcription factor (Sossey-Alaoui et al, 2014) and enhanced $\beta_{1}$ integrin activation. The association of kindlin-3 with $\mathrm{BC}$ has been corroborated by some studies (Djaafri et al, 2014), although not all other studies (Azorin et al, 2018). In the present work, we establish that kindlin-3 phosphorylation is crucial for kindlin-3 function in BC cells and other cell types, including platelets, megakaryocytes, and human erythroleukemia (HEL) megakaryocytic-like cells.

\section{Results}

\section{Development of kindlin-3 phosphoantibodies}

Our previous work has shown that stimulation of HEL megakaryocytic cells or human platelets with agonists significantly increased kindlin3 phosphorylation as detected by mass spectrometry (Bialkowska et al, 2015). $T^{482}$ or $S^{484}$ was identified as a phosphorylation site, but which of the two residues was modified could not be distinguished. These residues reside in a sequence that is unique to kindlin-3, and it is not conserved in kindlin-1 or kindlin-2. To further explore the significance of this unique posttranslational modification, we sought to generate phospho-specific antibodies to provide facile and flexible detection reagents. Two phosphopeptides of 11 amino acids (C-LSLQRTGPSGG and C-LSLQRpTGSGG) were injected as KLH conjugates into mice, and sera or hybridoma supernatants and ultimately purified IgG were obtained and tested for reactivity by ELISA on immobilized phosphopeptides and by Western blots of platelet lysates. The phosphothreonine antibody $1 \mathrm{C} 6$ showed specific binding to phosphothreonine peptide in ELISA (data not shown) but negligible reactivity with kindlin-3 in platelet extracts from either resting or PMA-stimulated platelets by Western blots (Fig S1) and, therefore, seemed to be of limited utility. In contrast, mAb $10 G 5$ to pS $^{484}$ peptide showed excellent specificity properties. In ELISA (Fig 1A), 10G5 bound specifically to the phosphoserine peptide and showed minimal reactivity with the non-phosphorylated peptide, the phosphothreonine peptide, and a control peptide containing a pS and/or a pT (Fig 1A). Next, we tested the reactivity of mAb 10G5 with HEL cells, a cell line with megakaryocytic properties, including expression of the major platelet integrin $\alpha_{11 \mathrm{~b}} \beta_{3}$ that can be activated to bind ligands (Jarvinen et al, 1987; Ylanne et al, 1988, 1990; Boudignon-Proudhon et al, 1996). Control and PMA-stimulated HEL cells were immunoprecipitated with anti-kindlin-3 antibodies, and the immunoprecipitates were probed by Western blots with antibodies against total kindlin-3 and mAb $10 \mathrm{G} 5$ to the $\mathrm{pS}^{484}$ peptide (Fig 1B). Anti-kindlin-3 antibodies, but not pre-immune serum, immunoprecipitated a single $\sim 72-\mathrm{kD}$ band (Fig 1B, total kindlin-3 blot). mAb $10 \mathrm{G} 5$ to $\mathrm{pS}^{484}$ peptide also blotted kindlin-3 in the immunoprecipitate, and this reactivity was neutralized by the presence of immunizing phosphopeptide (Fig 1B, 10G5 blots). Marked differences in reactivity between non-stimulated and PMA-stimulated HEL cells were observed with the mAb $10 \mathrm{G} 5$ to $\mathrm{pS}^{484}$ peptide (Fig 1B, 10G5, no peptide lane). These results are consistent with the induction of kindlin-3 phosphorylation upon PMA stimulation.

PKCS is a family of related serine/threonine kinases, which have been implicated in $\alpha_{\| \mathrm{b}} \beta_{3}$ integrin activation and outside-in signaling (Buensuceso et al, 2005; Soriani et al, 2006; Yacoub et al, 2006; Cifuni et al, 2008; Vilahur et al, 2018). It is well established that PKCs can be activated directly by phorbol esters, including PMA (Castagna et al, 1982; Kikkawa et al, 1983). Our previous work had suggested that PKC is involved in PMA-stimulated kindlin-3 phosphorylation using mass spectrometry to monitor the modification (Bialkowska et al, 2015). Here, HEL cells were stimulated with the PMA in the absence or presence of different concentrations of a membrane-permeable miristoylated $\mathrm{PKC}_{\alpha / \beta}$ inhibitor, N-MyrFARKGALRQ- $\mathrm{NH}_{2}$ (Ward \& O'Brian, 1993), and total lysates were blotted with mAb $10 \mathrm{G} 5$ to $\mathrm{pS}^{484}$. With PMA stimulation, kindlin-3 phosphorylation as detected with $10 \mathrm{G} 5$ antibody was increased when compared with unstimulated cells, but the $\mathrm{PKC}_{\alpha / \beta}$ inhibitor reduced mAb $10 G 5$ reactivity in Western blots (Fig 1C). Based on densitometric scanning, the $\mathrm{PKC}_{\alpha / \beta}$ inhibitor reduced the intensity of mAb $10 \mathrm{G} 5$ staining to $14 \%$ at $10 \mu \mathrm{M}, 12 \%$ at $20 \mu \mathrm{M}$, and $5 \%$ at $30 \mu \mathrm{M}$ relative to the MAb $10 \mathrm{G} 5$ band in cells stimulated with PMA alone. We also detected reductions in kindlin-3 phosphorylation with inhibitors for $\mathrm{PKC}_{\theta}$ and $\mathrm{PKC}_{\theta / \delta}$ isoforms, Myr-LHQRRGAIKQAKVHHVKC-NH ${ }_{2}$ and 5(3,4-Dimethoxyphenyl)-4-(1H-indol-5-ylamino)-3pyridinecarbonitrile, respectively (Osada et al, 1992; Cole et al, 2008) (data not shown), suggesting that more than one isoform of PKC might be involved directly or indirectly in kindlin-3 phosphorylation.

Further evidence for the reporter activity of mAb 10G5 to the $\mathrm{pS}^{484}$ peptide was derived from studies in which we stimulated $\mathrm{HEL}$ 

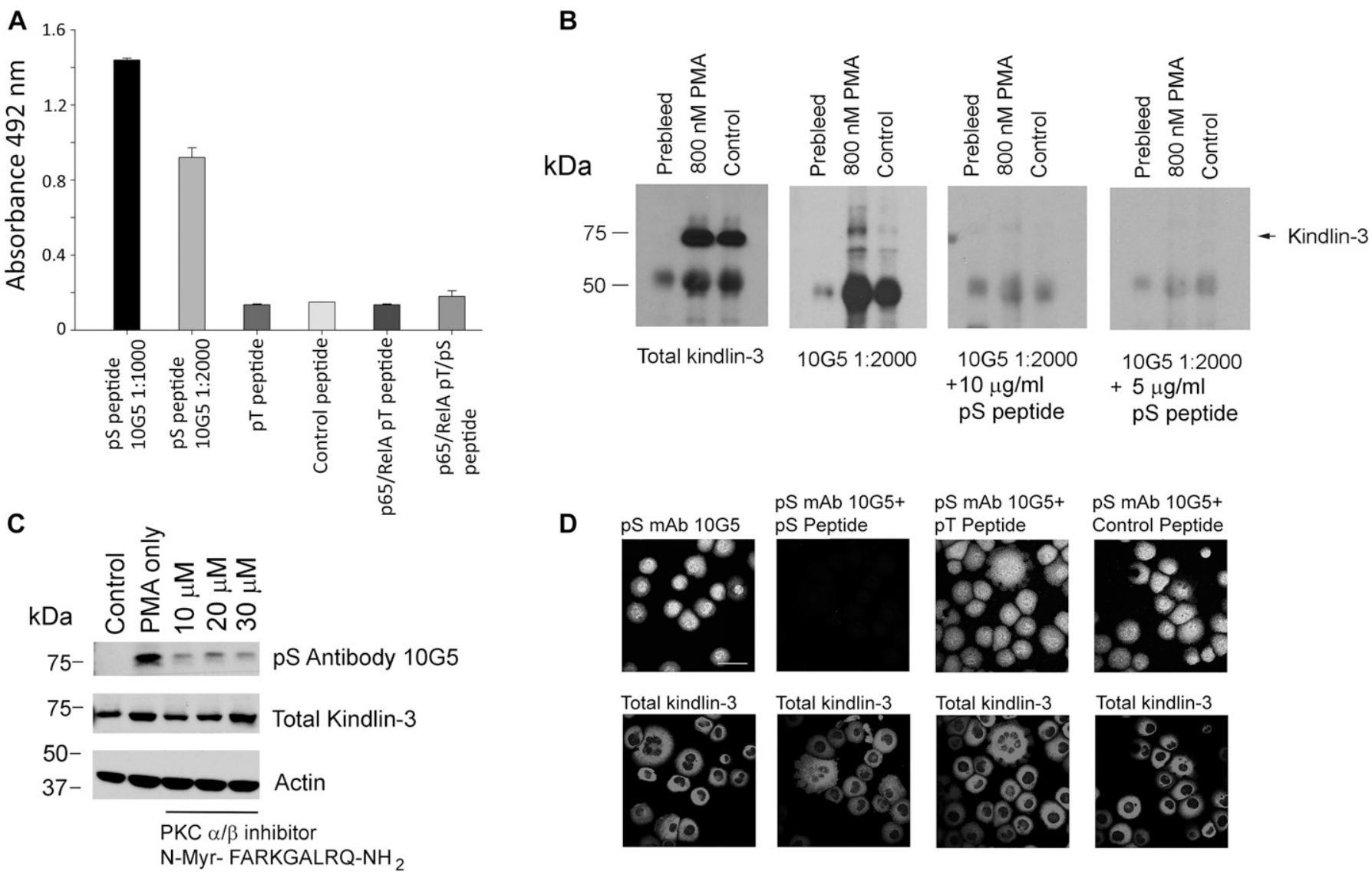

pS mAb 10G5+ pS Peptide
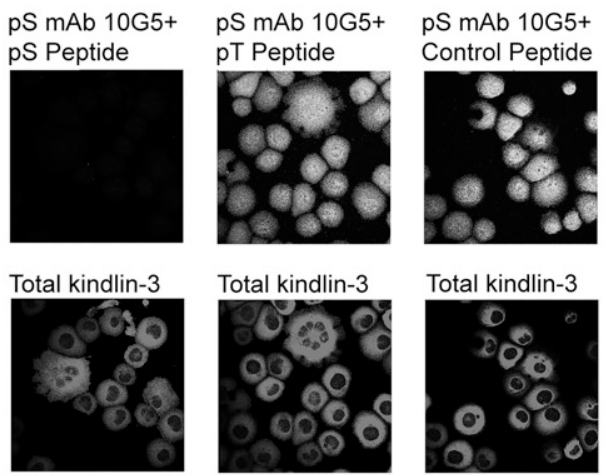

Figure 1. Phospho-kindlin-3-specific mAb.

(A) mAb $10 G 5$ to $\mathrm{S}^{484}$ was used in an ELISA assay. Indicated peptides were immobilized on the ELISA plate and incubated with $10 \mathrm{G} 5$ antibody. (B) Total kindlin-3 antibodies and mAb $10 G 5$ were used to blot immunoprecipitates from control and PMA-treated human erythroleukemia (HEL) cells in the absence or presence of phosphoserine peptide. (C) Total kindlin-3 antibodies, actin antibodies, and MAb $10 \mathrm{G5}$ were used to blot total lysates from control and PMA-treated HEL cells in the absence or presence of the PKC $\alpha$ / $\beta$ inhibitor N-Myr- FARKGALRQ- $\mathrm{NH}_{2}$ at 10, 20, or $30 \mu \mathrm{M}$. (D) PMA-stimulated HEL cells were allowed to spread on immobilized fibrinogen for $60 \mathrm{~min}$ in the absence of serum. The cells were fixed and stained with total kindlin-3 antibodies and mAb 10G5 in the absence or presence of indicated peptides. All peptides were used at $10 \mu \mathrm{g} / \mathrm{ml}$ concentration. Bar, $20 \mu \mathrm{m}$.

cells with $800 \mathrm{nM}$ PMA, and the cells were allowed to spread on immobilized fibrinogen for $60 \mathrm{~min}$ in the absence of serum. The cells were fixed and stained with total kindlin-3 antibodies and mAb $10 \mathrm{G} 5$ against $\mathrm{pS}^{484}$ in the absence or presence of immunizing peptide (Fig 1D). Staining for total kindlin-3 was apparent and was not changed by the immunizing peptide (Fig 1D, bottom panels). Staining with mAb $10 \mathrm{G} 5$ was evident and was markedly diminished by phosphoserine peptide, but the phosphothreonine peptide or control and nonphosphorylated peptide had no effect (Fig 1D, upper panels).

With this evidence of appropriate specificity, we sought to use the mAb $10 \mathrm{G} 5$ to $\mathrm{pS}^{484}$ on kindlin-3 status in platelets. Kindlin-3 phosphorylation as observed by mass spectroscopy occurred in platelets upon thrombin or PMA stimulation; maximal kindlin-3 phosphorylation was observed in the presence of EDTA, which prevents platelet aggregation, but still allows integrin activation (Bialkowska et al, 2015). We used mAb $10 \mathrm{G5}$ to $\mathrm{ps}^{484}$ to follow the time course of kindlin-3 phosphorylation in platelets stimulated with $1 \mathrm{U}$ of thrombin in the absence or presence of $10 \mathrm{mM}$ EDTA for 1 , 2,5 , or 10 min or in the presence of 800 nM PMA for 2 and 5 min. Total platelet lysates were assessed by Western blotting with mAb $10 \mathrm{G} 5$. Little kindlin-3 $S^{484}$ phosphorylation was detected in unstimulated platelets (Fig 2A, top panel, 0 min). With thrombin stimulation, kindlin-3 phosphorylation increased rapidly and was readily detected at $1 \mathrm{~min}$. This level diminished over time and returned to basal levels by 5 min (Fig 2A, top panel, lanes with no EDTA). When platelets were prevented from aggregating with EDTA (Fig 2A, top panel, lanes with EDTA), kindlin-3 phosphorylation increased and was more stable. Also stimulation with $800 \mathrm{nM}$ PMA increased kindlin-3 phosphorylation, but to a lesser extent than thrombin stimulation (Fig 2A, top panel, lanes with PMA). Similar patterns of kindlin-3 phosphorylation were observed in two additional experiments using platelets from different donors (Fig S2). Immunoreactivity with mAb $10 \mathrm{G} 5$ was markedly diminished in the presence of phosphoserine peptide (Fig 2A, middle panel), indicative of specificity. As a reference point for comparison, phosphorylation of Src on $\mathrm{Y}^{416}$, a hallmark of Src activation (Hunter, 1987; Shattil, 2005), also followed a transient pattern (Fig 2B, top panel), although Src phosphorylation occurred less rapidly in the presence of EDTA when compared with kindlin-3 phosphorylation on $\mathrm{S}^{484}$. 
A $\mathrm{kDa}$

75-

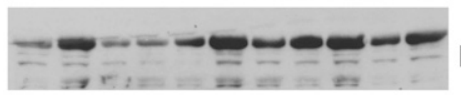

pS Antibody $10 \mathrm{G} 5$

$75-$

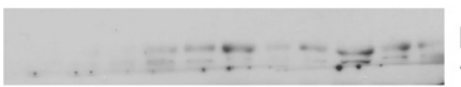

pS Antibody 10G5

+ Blocking Peptide

75-

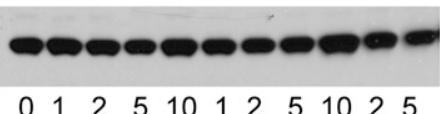

Total Kindlin-3

min: $\begin{array}{lllllllllll}0 & 1 & 2 & 5 & 10 & 1 & 2 & 5 & 10 & 2 & 5\end{array}$

Thrombin: -++++++++-

PMA: - $-\quad-\quad-\quad-\quad-\quad-++$

- EDTA + EDTA

B $\mathrm{kDa}$

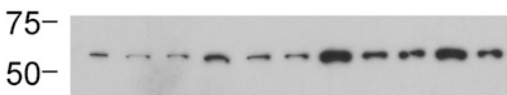

Phospho-Src Y416

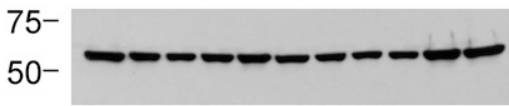

Total Src

$50-$

$37-$

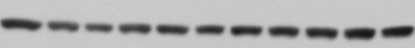

Actin

min: $\quad \begin{array}{lllllllllll}0 & 1 & 2 & 5 & 10 & 1 & 2 & 5 & 10 & 2 & 5\end{array}$

Thrombin: -++++++++-

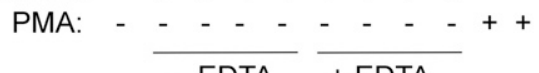

- EDTA + EDTA

Figure 2. Comparison of kindlin-3 phosphorylation and Src phosphorylation in agonist-stimulated human platelets.

(A, B) Platelet suspensions were stirred in the presence of $1 \mathrm{U}$ of thrombin alone or in the presence of $10 \mathrm{mM}$ EDTA or in the presence of PMA for the times indicated. Incubations were terminated by addition of $2 \times$ Laemmli sample buffer. (A, B) Total kindlin-3 (loading control), phosphorylated kindlin-3 (A), phosphor-Src, total Src, and actin (loading control) (B) were detected on Western blots. Phosphoserine blocking peptide was used at $10 \mu \mathrm{g} / \mathrm{ml}$. The blots are representative of three independent experiments; two other experiments are shown in Fig S2.

To further assess the importance of kindlin-3 phosphorylation in regulation of $\alpha_{11} \beta_{3}$ activation, megakaryocytes were isolated from the bone marrow of mice with low expression of kindlin-3 ( $10 \%$ of kindlin-3 levels in WT mice), which, according to Klapproth et al (2015), is sufficient to prevent spontaneous bleeding). The procedure of Shiraga et al (1999) was used to isolate megakaryocytes, which were then infected with lentivirus constructs for human EGFP-tagged WT kindlin-3, $T^{482} S^{484} / A A$ kindlin-3, and $Q^{597} W^{598} / A A$ kindlin-3. The double $\mathrm{T}^{482} \mathrm{~S}^{484} / \mathrm{AA}$ kindlin-3 mutant was used to preclude phosphorylation of $\mathrm{T}^{482}$ if $\mathrm{S}^{484}$ was not available or vice versa and our previous demonstration that the $\mathrm{T}^{482} \mathrm{~S}^{484} / \mathrm{AA}$ expressed well and retained many kindlin-3 functions (Bialkowska et al, 2015). On day 2 postinfection, $\alpha_{\| b} \beta_{3}$ integrin activation was assessed on EGFP-gated population only using mAb JON/A, which is specific for activated mouse $\alpha_{\| b} \beta_{3}$ integrin (Bergmeier et al, 2002), with or without PAR- 4 agonist. When normalized to total $\alpha_{\| 1} \beta_{3}$ integrin expression, wild-type, control megakaryocytes, expressing endogenous kindlin-3 increased their integrin activation almost twofold upon agonist stimulation (Fig 3, WT kindlin-3). Megakaryocytes

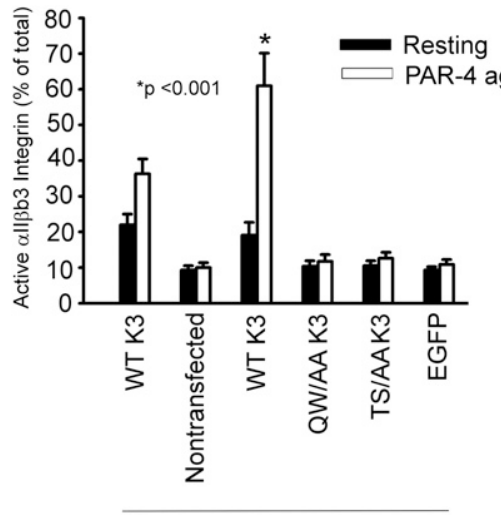

Experiment 1

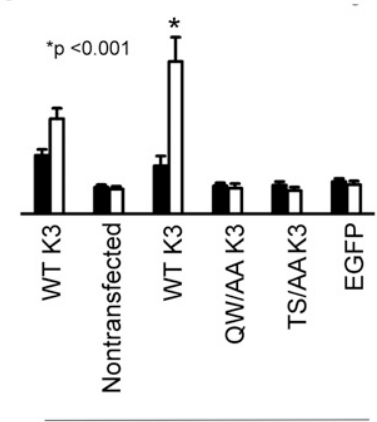

Experiment 2
Figure 3. Effect of kindlin-3 variants on activation of $\alpha_{1 \mathrm{lb}} \beta_{3}$ in megakaryocytes. Bone marrow megakaryocytes were isolated from mice with low expression of kindlin-3 and transduced with lentiviruses to express EGFP-WT kindlin-3, EGFP$\mathrm{Q}^{597} \mathrm{~W}^{598} / \mathrm{AA}$ kindlin-3, EGFP-T ${ }^{482} \mathrm{~S}^{484} / \mathrm{AA}$ kindlin-3, or EGFP alone and were then either untreated or stimulated with PAR-4 agonist peptide. $\alpha_{11 b} \beta_{3}$ integrin activation was measured by flow cytometry in EGFP-positive cell populations using PE-labeled Ab to activation-dependent epitope of $\alpha_{11 \mathrm{~b}} \beta_{3}$ (clone JON/A) or total $\alpha_{\| \mathrm{b}} \beta_{3}$ with rat antimouse CD41-PerCP/Cy5.5. The data are expressed as \% activation $=($ MFI JONA/MFI total CD41) $\times 100$. The error bars represent means \pm SE $\left({ }^{*} P<0.001\right.$, two-tailed $t$ test). The left and right data sets are from two independent experiments, with triplicates performed in each experiment.

from the mice with low kindlin-3 failed to activate $\alpha_{\| b} \beta_{3}$ integrin even upon agonist stimulation (Fig 3, non-transfected). Megakaryocytes overexpressing WT kindlin-3 increased $\alpha_{\| b} \beta_{3}$ integrin activation upon PAR4 agonist stimulation as measured by JON/A binding (Fig 3, WT kindlin-3). In contrast, megakaryocytes expressing $\mathrm{T}^{482} \mathrm{~S}^{484} / \mathrm{AA}$ kindlin-3 failed to activate $\alpha_{\| 1 \mathrm{~b}} \beta_{3}$ integrin. A similar failure to activate was observed in megakaryocytes expressing $\mathrm{Q}^{597} \mathrm{~W}^{598} / \mathrm{AA}$ kindlin-3 or EGFP alone (Fig 3). These results were replicated in two independent experiments (Fig 3).

To determine the impact of kindlin-3 phosphorylation in a nonhematopoietic cell, we tested the triple-negative BT549 BC cell line, which expresses high levels of kindlin-3 (Sossey-Alaoui et al, 2014) (Fig S3, BT549 lane) for reactivity with mAb 10G5. BT549 cells were serum-starved overnight and then treated with $50 \mathrm{nM}$ calyculin A, a potent phosphatase inhibitor (Resjo et al, 1999) for $10 \mathrm{~min}$ in the absence or presence of 800 nM PMA, and total cell lysates were assayed by Western blotting for phosphorylated kindlin-3 with mAb 10G5. There was very little or no kindlin-3 phosphorylation of $\mathrm{S}^{484}$ in control, unstimulated BT549 cells (Fig 4A, lane 1). Treatment of the cells with a $50 \mathrm{nM}$ calyculin A increased kindlin-3 phosphorylation rapidly (Fig 4A, line 2), and this level was further enhanced by addition of PMA (Fig 4A, lane 3). Similar patterns of kindlin-3 phosphorylation were observed in two additional independent experiments (Fig S4).

Spreading assays were also performed on parental BT549 cells that had been rendered deficient in kindlin-3 using CRISPR/Cas9 technology. As shown in Fig S2, the two sgRNAs deleted kindlin-3 but did not alter kindlin-2 expression. The cells were allowed to spread on immobilized fibronectin for $1 \mathrm{~h}$ and then stained with total kindlin-3 antibodies, mAb $10 \mathrm{G} 5$ against kindlin-3 $\mathrm{pS}^{484}$ and phalloidin for actin. The immunofluorescent micrographs in Fig 4B show strong staining of the parental BT549 cells for total kindlin-3 and phosphorylated 
A
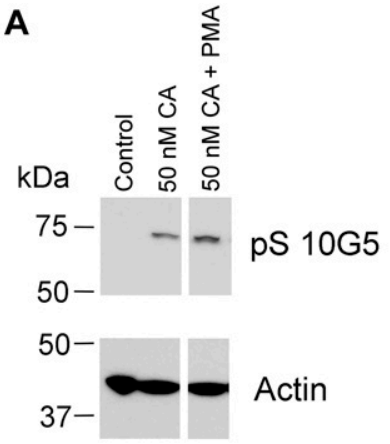

B

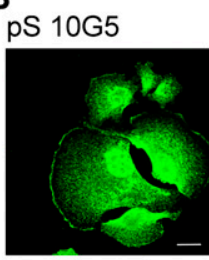

pS $10 \mathrm{G} 5$

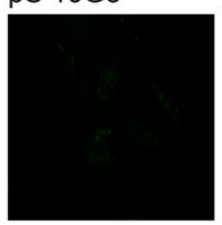

Total kindlin-3

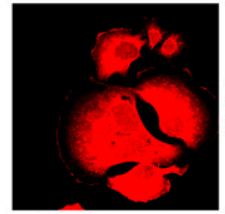

Total kindlin-3

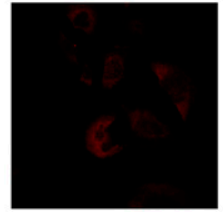

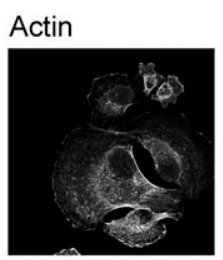

BT549

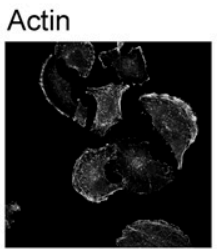

\section{$\mathrm{K} 3 \mathrm{KO}$}

A

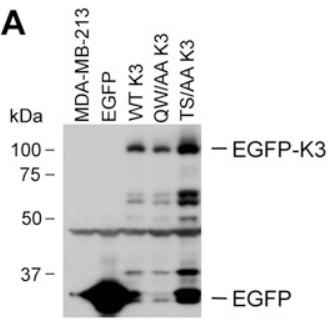

C

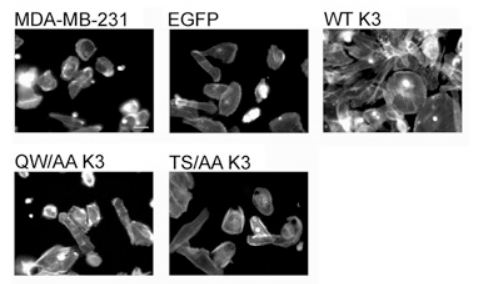

E

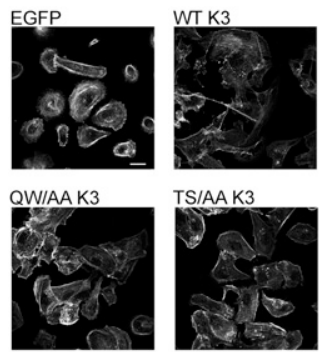

B

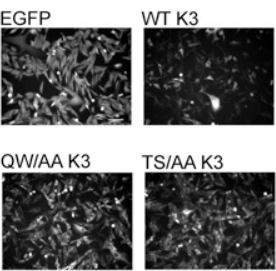

Figure 4. Kindlin-3 phosphorylation in BT549 cells.

(A) BT549 cells were treated with calyculin A in the absence or presence of 800 nM PMA. Incubations were terminated by addition of $2 \times$ Laemmli sample buffer and phosphorylated kindlin-3 and actin (loading control) were detected on Western blots. The blots are representative of three independent experiments; two other experiments are shown in Fig S4. (B) BT549 parental cells and BT549 kindlin-3-deficient cells were allowed to spread on immobilized fibronectin for 60 min in the absence of serum. The cells were fixed and stained with total kindlin-3 antibodies and mAb 10G5 to ps ${ }^{484}$. Bar, $20 \mu \mathrm{m}$.

kindlin-3 (Fig 4B, top panels), whereas the staining was negligible for both kindlin-3 and pS-kindlin-3 in the kindlin-3 KO BT549 cells. Thus, using three different cell types, megakaryocyte-like, platelets, and a $\mathrm{BC}$ cell line, kindlin-3 is shown to undergo phosphorylation, and the level of its phosphorylation was enhanced by stimulation of the cells or reducing phosphatase activity.

\section{Kindlin-3 phosphorylation regulates BC cell properties and tumor progression in vivo}

Our previous work showed that kindlin-3 influences the growth and metastasis of triple-negative human BC lines in mice (SosseyAlaoui et al, 2014). To determine if kindlin-3 phosphorylation influences tumorogenic properties, we used MDA-MB-231 cells, which express relatively low levels of kindlin-3, to overexpress kindlin-3 mutants. cDNAs for WT-kindlin-3, a $T^{482} S^{484} / A A$ kindlin-3 or a kindlin-3 $Q^{597} / W^{598} / A A$, which disables its primary integrin-binding site, was overexpressed in these cells as EGFP fusions. Stable expression of the kindlin-3 variants or EGFP-alone was monitored by Western blots (Fig 5A) and EGFP fluorescence (Fig 5B). We first assessed the properties of these cells in in vitro analyses. In Boyden chamber invasion assays, significantly more kindlin-3-overexpressing
Figure 5. Kindlin-3-enhanced invasion and spreading of breast cancer cells in vitro is blunted in cells expressing $\mathrm{T}^{482} \mathrm{~S}^{484} / \mathrm{AA}$ kindlin-3.

(A) Immunoblots of total cell lysates from MDA-MB-231 cells expressing EGFP alone or EGFP-kindlin-3 constructs, probed with anti-EGFP. (B) Representative micrographs of EGFP-expressing and EGFP-kindlin-3-overexpressing MDA-MB231 cells in the culture visualized with EGFP fluorescence. Bar, $100 \mu \mathrm{m}$. (C) Representative micrographs of EGFP-expressing and EGFP-kindlin3-overexpressing MDA-MB-231 cells that were induced to invade through a Matrigel-coated membrane. The cells were visualized with Alexa-568 phalloidin to stain filamentous actin. Bar, $50 \mu \mathrm{m}$. (D) Invading cells were counted from 10 different fields and plotted as an average of the number of invading cells per field $\left({ }^{\star} P<0.001\right.$, two-tailed $t$ test). The error bars represent means $\pm \mathrm{SE}$. The left and right data sets are from two independent experiments. (E) Representative micrographs of EGFP-expressing and EGFP-kindlin-3-overexpressing MDA-MB231 cells spreading on fibronectin for $1 \mathrm{~h}$. The cells were visualized with Alexa-568 phalloidin to stain filamentous actin. (F) The areas of cells were measured using Image) software, and 300 cells were quantified in each experiment $\left({ }^{*} P<0.001\right.$, two-tailed $t$ test). The error bars represent means $\pm \mathrm{SE}$. The left and right data sets are from two independent experiments. Bar, $10 \mu \mathrm{m}$.

cells traversed the Matrigel-coated inserts and invaded the lower chamber as compared with the cells expressing EGFP alone (Fig $5 \mathrm{C}$ and $\mathrm{D}$ ). This response is consistent with that previously observed with stably transfected MDA-MB-231 cells (Sossey-Alaoui et al, 2014), indicating that kindlin-3 confers enhanced migratory/invasive advantage to these BC cells. The enhanced invasion of the kindlin-3overexpressing MDA-MB-231 cells was significantly blunted in cells not only expressing kindlin-3 $Q^{597} W^{598} / A A$ but also kindlin-3 $T^{482} S^{484}$ / $A A$, which emphasizes the importance of kindlin-3 phosphorylation in the invasive properties of these cancer cells.

We next assessed the capacity of the $\mathrm{T}^{482} \mathrm{~S}^{484} / \mathrm{AA}$ kindlin-3 mutant in integrin-mediated cell spreading. The transfected MDA-MB-231 
cells were plated onto fibronectin for 30 min, they were fixed and actin visualized with Alexa-568 phalloidin, and the cell area was determined by measuring the area of 100 cells for each of the constructs. Compared with control EGFP-expressing cells, the cells transfected with WT kindlin-3 exhibited markedly enhanced spreading (Fig 5E). In contrast, $\mathrm{T}^{482} \mathrm{~S}^{484} / \mathrm{AA}$ kindlin-3-expressing cells had areas similar to EGFP-expressing cells, which were also similar to the effect of $Q^{597} W^{598} / A A$ kindlin-3, observations consistent with the importance of phosphorylation in integrin-induced spreading of these BC cells (Fig 5F). These results were replicated in two independent experiments (Fig 5F).

To evaluate the effects of kindlin-3 phosphorylation in an in vivo setting, we performed tumor growth assays in mice. MDA-MB-231 cells expressing the kindlin-3 variants were implanted in the mammary fat pads of NSG mice, and tumor growth was assessed over 7-9 wk. Although every mouse in the EGFP-alone and WT kindlin-3 groups developed tumors (100\% tumor incidence) after a 4-wk latency period, the tumor burden was significantly higher in the mice implanted with the kindlin-3-overexpressing cells. Tumors in mice implanted with cells expressing $\mathrm{T}^{482} \mathrm{~S}^{484} / \mathrm{AA}$ kindlin-3 were significantly smaller than those overexpressing WT kindlin-3 and also slightly smaller than tumors expressing EGFP alone (Fig 6A and B). Only two tumors expressing $Q^{597} W^{598} / A A$ kindlin-3 developed over a 9-wk period (Fig 6A), and these tumors were significantly smaller that tumors overexpressing WT kindlin-3 (Fig 6A and B). Thus, WT kindlin-3 enhances the rate of tumor growth in vivo, and this effect is dependent on kindlin-3 phosphorylation as well as integrin binding.

With the profound effect of kindlin-3 phosphorylation on tumor growth, we examined some of the molecular events known to be kindlin-3-dependent. First, we considered the expression and activation of integrins on the surface of the MDA-MB-231 transfectants. We had previously reported that both total surface expression (measured with monoclonal antibody mAb 13) and activation of $\beta 1$-integrin (measured with HUTS-4, an antibody specific for activated $\beta_{1}$ integrins (Luque et al, 1996) increased in MDA-MB-231 cells overexpressing WT kindlin-3 versus EGFP controls

A

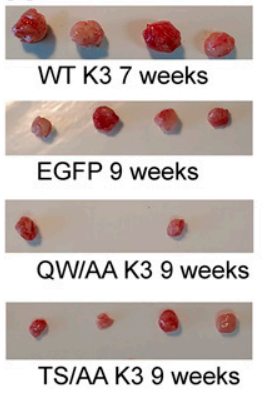

B

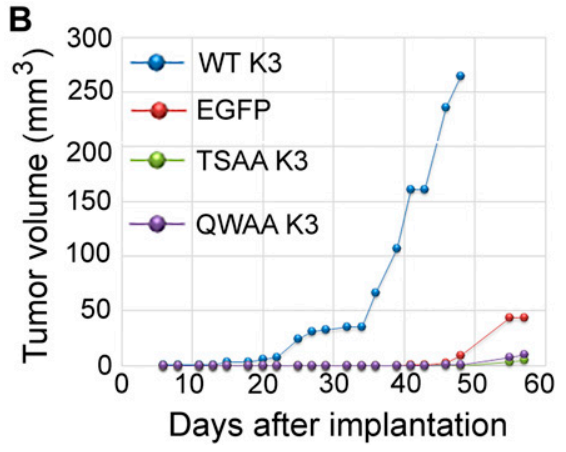

Figure 6. WT kindlin-3 enhances primary tumor growth of breast cancer in vivo in mouse models, and tumor growth is blunted for cells expressing $\mathrm{T}^{482} \mathrm{~S}^{484} \mathrm{I}$ AA kindlin-3.

(A) Tumors generated from inoculation of EGFP or EGFP-kindlin-3-expressing MDA-MB-231 cells into the mammary fat pads of NSG mice. (B) Tumor growth curves for EGFP-expressing and EGFP-kindlin-3-overexpressing MDA-MB-231 cells. Data points represent means \pm SE of tumor volume. as assessed by flow cytometry (Sossey-Alaoui et al, 2014). When normalized to total $\beta 1$ integrin expression, WT kindlin-3-overexpressing cells increased $\beta_{1}$ integrin activation measured by HUTS- 4 binding (Fig 7). In contrast, integrin activation in cells expressing $T^{482} S^{484} / A A$ kindlin-3 was similar to activation in EGFP-expressing cells. Cells expressing the $\mathrm{Q}^{597} \mathrm{~W}^{598} / \mathrm{AA}$ kindlin-3 also showed minimal integrin activation (Fig 7).

One of the major characteristic of the neoplastic transformation is epithelial-to-mesenchymal transition (EMT), which is characterized by acquisition of high mobility and a fibroblastoid apolar phenotype. One of the hallmarks of EMT is the up-regulation of specific markers, including $\mathrm{N}$-cadherin and fibronectin. Cells expressing WT kindlin-3 enhanced EMT markers expression and enhanced fibronectin deposition (Fig $8 \mathrm{~A}$ and B). Tumors derived from WT kindlin-3-overexpressing cells show increased $\mathrm{N}$-cadherin expression (Fig 8C), when compared with tumor derived from EGFPexpressing cells. Fibronectin deposition and $\mathrm{N}$-cadherin expression (Qu et al, 2014) were significantly blunted in tumors derived from $\mathrm{T}^{482} \mathrm{~S}^{484} / \mathrm{AA}$ kindlin-3-expressing cells (Fig 8A-C), emphasizing the importance of kindlin-3 phosphosite in enhancing the expression of EMT markers.

Angiogenesis is critical for tumor growth; hence, we determined whether kindlin-3 phosphorylation affected tumor microvasculature. IHC using antibody to Von Willebrand factor (vWf) and CD31, endothelial cell markers, revealed a significant increase in the number and size, as well as a dismorphic architecture of blood vessels in tumors from WT kindlin-3-overexpressing compared with EGFP-expressing cells (Fig 9A-C), as reported previously (Sossey-Alaoui et al, 2014). The numbers and size of the blood vessels from tumors expressing $\mathrm{T}^{482} \mathrm{~S}^{484} / \mathrm{AA}$ kindlin-3 were significantly decreased when compared

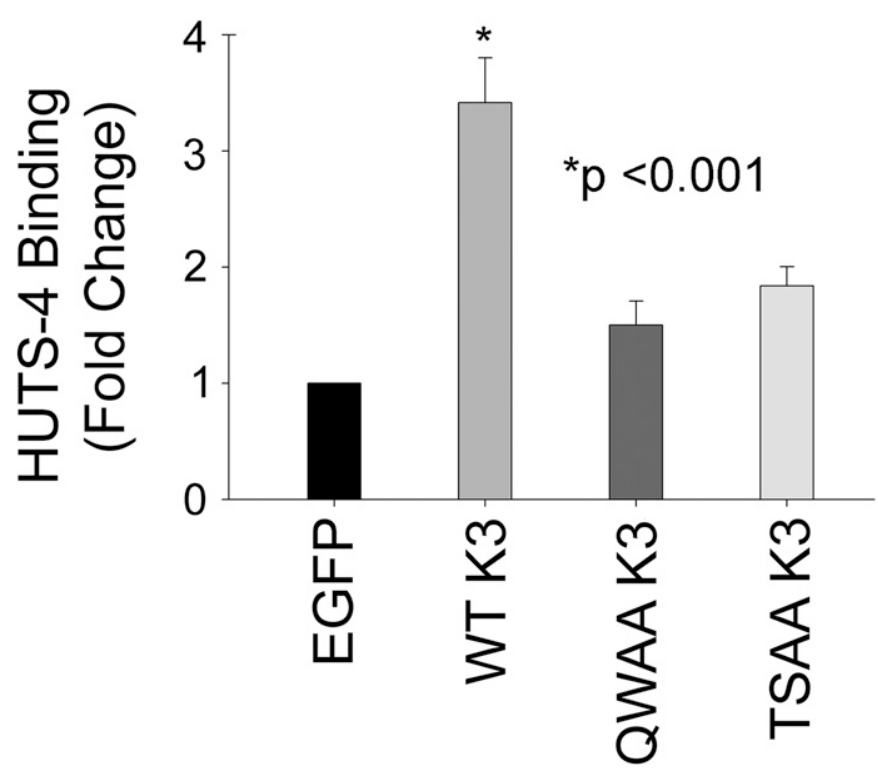

Figure 7. Quantification of cell surface $\beta_{1}$-integrin activation in MDA-MB-231 cells.

Activation was measured in the EGFP-expressing and EGFP-kindlin-

3-overexpressing MDA-MB-231 cells using HUTS4 antibody binding, normalized to total $\beta_{1}$-integrin expression levels, and plotted as a fold change to the EGFPexpressing cells. The error bars represent means \pm SE of three independent experiments ( ${ }^{*} P<0.001$, two-tailed $t$ test). 
A

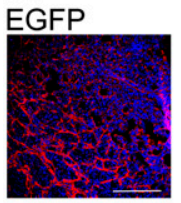

QWIAAK3

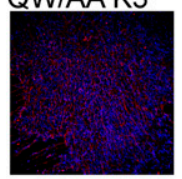

Blue: DAPI
Red: Fibronectin

B

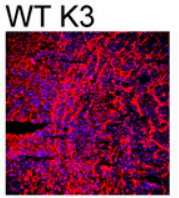

TS/AA K3

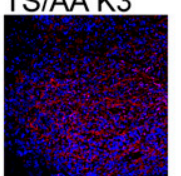

$\cos ^{2}+\sin ^{2}$

C

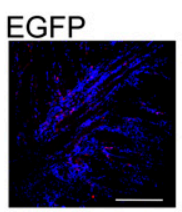

QW/AAK3

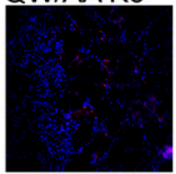

Blue - DAPI

Red - N-cadherin

Figure 8. Kindlin-3-mediated regulation of the epithelial-to-mesenchymal transition program in breast cancer depends on kindlin-3 phosphorylation. (A) Representative immunofluorescence confocal micrographs of sections of mammary fat pad tumors derived from EGFP-expressing and EGFP-kindlin3-overexpressing MDA-MB-231 cells, stained with anti-fibronectin (red fluorescence). Cell nuclei were counterstained with DAPI. Bar, $200 \mu \mathrm{m}$. (B) Quantification of fibronectin area in the tumors described in (B), as determined by the average fibronectin-positive area per tumor section. The fibronectin-positive areas were measured using Imagel software, and 20 fields were quantified per group ( ${ }^{*} P<0.001$, two-tailed $t$ test). (c) Representative immunofluorescence confocal micrographs of sections of mammary fat pad tumors derived from EGFP-expressing and EGFP-kindlin-3-overexpressing MDAMB-231 cells, stained with anti-N-cadherin (red fluorescence). Cell nuclei were counterstained with DAPI. Bar, $200 \mu \mathrm{m}$.

with tumors expressing WT kindlin-3 and similar to those from EGFP-expressing and the tumors and the $\mathrm{Q}^{597} \mathrm{~W}^{598} / \mathrm{AA}$ kindlin-3 (Fig 9A-C).

Tumor angiogenesis is highly dependent on secretion of angiogenic growth factor VEGF by tumor cells, and kindlins have been shown to influence VEGF production (Sossey-Alaoui et al, 2014). This effect of kindlin-3 is shown with the MDA-MB-231 cell lines as WT kindlin-3-overexpressing cells increased their release of VEGF by almost threefold compared with the EGFP-control cells. In contrast, $\mathrm{T}^{482} \mathrm{~S}^{484} / \mathrm{AA}$ kindlin-3 cells exhibited a minimal increase in VEGF release and similar to the level released from the $Q^{597} W^{598} / A A$ kindlin-3 cells (Fig 10A). These results were replicated in two independent experiments (Fig 10A). The transcription factor Twist has been shown to be a master regulator of cancer metastasis by promoting tumor angiogenesis (Mironchik et al, 2005). In cells overexpressing WT kindlin-3, Twist protein expression was elevated
A
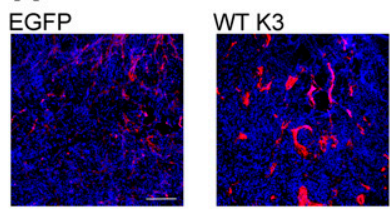

QWIAAK3

TS/AA K3

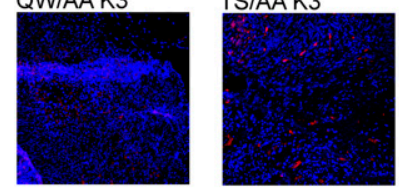

Blue -DAPI

Red - vWf
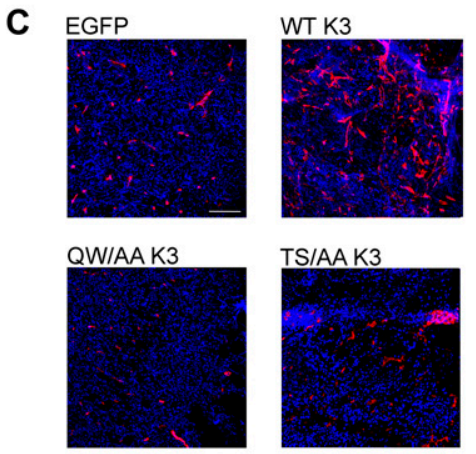

QWIAAK3

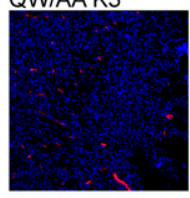

TS/AAK3

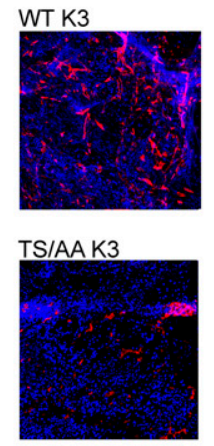

Blue -DAP

Red - CD31

B

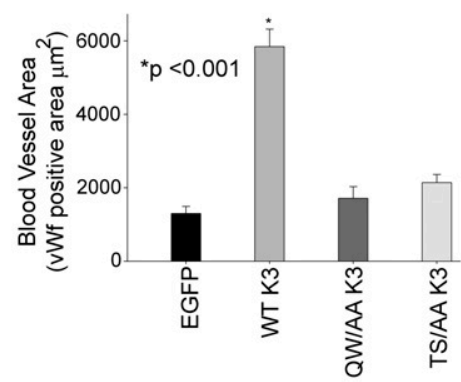

umors formed by cells expressing Figure 9. Angiogenesis
$\mathrm{T}^{482} \mathrm{~S}^{484} / \mathrm{AA}$ kindlin-3.

(A) Representative immunofluorescence confocal micrographs of sections of mammary fat pad tumors from mice implanted with EGFP-kindlin-3 or EGFPexpressing MDA-MB-231 cells stained with anti-vWf (red) to detect tumorassociated blood vessels. Cell nuclei were counterstained with DAPI (blue). Bar, $200 \mu \mathrm{m}$. (B) Quantification of angiogenesis from the EGFP and kindlin-3 groups, as determined by the average blood vessel area per tumor section. The areas of vessels were measured using Imagel software, and 20 fields were quantified per group ( ${ }^{\star} P<0.001$, two-tailed $t$ test). (C) Representative immunofluorescence confocal micrographs of sections of mammary fat pad tumors from mice implanted with EGFP-kindlin-3-overexpressing MDA-MB-231 or EGFP-expressing and cells stained with anti-CD31 (red) to detect tumor-associated blood vessels. Cell nuclei were counterstained with DAPI (blue). Bar, $200 \mu \mathrm{m}$.

compared with cells expressing control EGFP. As shown in Fig 10B, Twist expression was readily detected in cells overexpressing WT kindlin-3. However, little or no Twist could be detected not only in the cells expressing $Q^{597} W^{598} / A A$ but also in the cells expressing $\mathrm{T}^{482} \mathrm{~S}^{484} / \mathrm{AA}$ kindlin-3 (Fig 10B). As a control, the levels of another transcription factor, Snail, remained unchanged regardless of the form of kindlin-3 expressed (Fig 10B) in the cells.

\section{Discussion}

Kindlins play an indispensable role in integrin activation in many hematopoietic and non-hematopoietic cells, but the mechanisms by which they impact integrin activation remain largely unresolved. Phosphorylation is emerging to be such a regulatory mechanism. Kindlin-2 phosphorylation on $\mathrm{Y}^{193}$ by Src and kindlin-2-Src interaction 
A

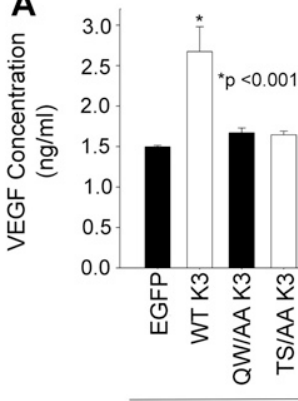

Experiment 1
B

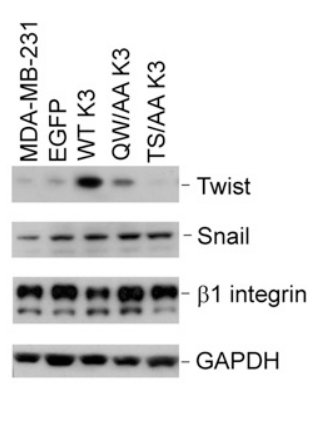

Figure 10. Kindlin-3 enhanced VEGF secretion and Twist expression is blunted in cells expressing $\mathrm{T}^{482} \mathrm{~S}^{484} / \mathrm{AA}$ kindlin-3.

(A) Quantification of secreted VEGF-A in the conditioned media of EGFP-expressing and EGFP-kindlin-3-overexpressing MDA-MB-231 cells using ELISA. MDA-MB-231 cells were cultured in serum-free DMEM medium for $24 \mathrm{~h}$ before experiment. The error bars represent means $\pm \mathrm{SE}\left({ }^{*} P<0.001\right.$, two-tailed $t$ test). The left and right data sets are from two independent experiments, with triplicates performed in each experiment. (B) Immunoblotting with the indicated antibodies of cell lysates from EGFP-expressing and EGFP-kindlin-3-expressing MDA-MB-231.

regulates integrin outside-in signaling and controls cell migration and proliferation (Qu et al, 2014). Reciprocally, kindlin-2 $Y^{193}$ phosphorylation activates and maintains Src kinase activity (Liu et al, 2015). Calpain cleaves kindlin-3 at $\mathrm{Y}^{373}$ in response to cell stimulation and/or an increase in intracellular calcium (Zhao et al, 2012), which in turn regulates the dynamics of the interaction between $\beta$ integrin subunit and kindlin-3. In our previous study (Bialkowska et al, 2015), we identified agonist-induced kindlin-3 phosphorylation on $T^{482}$ and/or $\mathrm{S}^{484}$ in HEL cells and platelets. The identified phosphosite resides in highly variable region of kindlin-3 and at least one of the two residues, $\mathrm{T}^{482}$ or $\mathrm{S}^{484}$, is evolutionarily conserved in all kindlin-3 orthologues analyzed, including mouse, bovine, and zebrafish kindlin-3.

In this study, we developed mAbs against phosphorylated kindlin3 and showed that $10 \mathrm{G} 5$ clone specifically recognizes $\mathrm{ps}^{484}$ in different cell types, including platelets, megakaryocytic cells and $\mathrm{BC}$ cells, and this phosphorylation was enhanced by agonist stimulation. The experimental usefulness of phosphospecific antibodies is limited by the extent to which they exhibit specificity. For mAb 10G5, specificity for kindlin-3 $\mathrm{pS}^{484}$ was demonstrated by the following: 1) neutralization of immunoblot reactivity in the presence of specific phosphopeptide in HEL cells and platelets (Figs $1 \mathrm{~A}$ and 2A); 2) immunoreactivity in HEL cells spreading on integrin substrate, which diminished in the presence of specific phosphopeptide but not in the presence of non-phosphorylated peptides (Fig 1B); 3) increase in immunoblot reactivity in the presence of calyculin $A$ and PMA treatment in BT549 BC cell line (Fig 4A); 4) and the lack of reactivity in BT549 cells lacking kindlin-3 expression (Fig 4B).

In our previous work, we used mass spectrometry to show that thrombin induced phosphorylation of kindlin-3. It appeared that the phosphorylation of kindlin-3 was followed by rapid dephosphorylation in aggregating platelets (Bialkowska et al, 2015). Here, phosphospecific antibody allowed us to not only confirm but to extend on these observations. As disclosed by the $\mathrm{pS}^{484} \mathrm{mAb}$, kindlin3 phosphorylation was rapid, clearly detected within 1 min after thrombin stimulation, and the phosphorylation diminished by 5 min in the absence of EDTA. In the presence of EDTA, which prevented the

platelets from aggregating, the increase in kindlin-3 phosphorylation was sustained for at least 10 min when platelets were present. This pattern is not unusual for platelet proteins, which undergo a myriad of rapid phosphorylation/dephosphorylation reactions in response to various platelet agonists (Zimman et al, 2014; Beck et al, 2017). For time course experiments, we choose to compare kindlin-3 phosphorylation with Src, although the Scr phosphorylation was monitored on a tyrosine, $\mathrm{pY}^{464}$, as contrasted in a serine, $\mathrm{pS}^{484}$, of kindlin-3. Impetus for this comparison resides in the fact that both kindlin and Src have been implicated in outside-in signaling (Shattil, 2005; Feng et al, 2012; Xue et al, 2013; Liao et al, 2015; Bledzka et al, 2016) and, importantly, both bind to the extreme $C$-terminal end of $\beta_{3}$ integrin. Recent data from Liao et al (2015) suggests that kindlin-3 is the preferred binding partner, and its phosphorylation does seem to be slightly more rapid. Phosphorylation of kindlin-3 does not appear to prevent its binding to $\beta_{3}$ integrin (Bialkowska et al, 2015). However, the role of kindlin-3 in outside-in signaling does not exclude a role in inside-out signaling as well (Ye et al, 2013). The failure of the mutant $\mathrm{T}^{482} \mathrm{~S}^{484} / \mathrm{AA}$ kindlin-3 to support cell spreading would be consistent with such a role.

The mechanism by which phosphorylation activates kindlin-3 remains to be determined. This posttranslational modification does appear to be PKC dependent based on the effects of specific inhibitors and consistent with our previous findings (Bialkowska et al, 2015). Our inhibitor studies implicate $\mathrm{PKC}_{\alpha / \beta}$ in the phosphorylation process, but $\mathrm{PKC}_{\delta / \theta}$ may also be involved in a network leading to the posttranslational modification itself or the extent of the modification. Because $\mathrm{S}^{484}$ resides in a region that is not conserved among the kindlins, the crystal structure of kindlin-2 ( $\mathrm{Li}$ et al, 2017) is not insightful. Molecular modeling of kindlin-3 using the ROBETTA program (Kim et al, 2004) suggested that $\mathrm{T}^{482} \mathrm{~S}^{484}$ of kindlin-3 resides at the hydrated surface. In this orientation, phosphorylation could support binding of a phosphor-specific partners. However, it is unclear if any of the reported binding partners of kindlins (Plow et al, 2016) interacts uniquely with kindlin-3. Alternatively, it has been reported that dimerization of kindlin-2 regulates its integrin activation function (Li et al, 2017) and phosphorylation could regulate the association between kindlin-3 molecules. These possibilities remain to be investigated in future studies.

Although kindlin-3 is highly expressed in the hematopoietic system, there are only limited reports about its involvement in blood cell cancers, and a role of kindlin-3 phosphorylation in cancer cell is not known. Kindlin-3 was found to be associated with both acute and chronic myeloid leukemias (Wu et al, 2012; Qu et al, 2015). Kindlin-3 may influence proliferation of human chronic myeloid leukemia K562 cells through its regulation of c-Myc protein expression and kindlin-3 controlled the growth of these cells in a xenograft model (Qu et al, 2015). Recent studies have identified kindlin-3 in solid tumors, but its role is controversial. A study by Djaafri et al (2014) failed to detect kindlin-3 in BC cells and concluded that kindlin-3 has tumor suppressor function when expressed MDA-MB-231 BC cells. However, independent evidence for the role of kindlin-3 in $\mathrm{BC}$ can be taken from interrogation of the Oncomine database (http:/ / www.oncomine.com) in which kindlin-3 ranked in the top $3 \%$ of up-regulated genes. Furthermore, in glioblastoma, kindlin-3 contributed to resistance to telozolomide and cell proliferation through Wnt signaling (Lu et al, 2017), whereas overexpression of kindlin-3 in 
melanoma cells led to imbalanced Rho GTP-ase activation and inhibition of cell migration (Feng et al, 2017).

In the present work, we found that kindlin-3 phosphorylation was a tumor promotor. We establish that kindlin-3 phosphorylation is crucial for kindlin-3 function in $\mathrm{BC}$ as supported by the following findings: kindlin-3 induced spreading and invasion in vitro and tumor progression, and metastasis in mice in vivo is blunted in $\mathrm{T}^{482} \mathrm{~S}^{484} / \mathrm{AA}$ kindlin-3 cells; kindlin-3 induced tumor angiogenesis, and macrophage recruitment is inhibited in $T^{482} S^{484} / A A$ kindlin-3 cells; Twist expression was significantly blunted in vitro and in tumors derived $\mathrm{T}^{482} \mathrm{~S}^{484} / \mathrm{AA}$ kindlin-3-expressing cells; kindlin-3-mediated regulation of the EMT program in BC depends on kindlin-3 phosphorylation. Collectively, our findings identify kindlin-3 phosphorylation as a novel and key mechanism of tumor promoter function of kindlin-3 in BC.

\section{Materials and Methods}

\section{Antibodies and reagents}

Mouse mAb against EGFP (B2) was from Santa Cruz Biotechnology; rat mAb against CD29 (Mab 13) and rat mAb against mouse CD31 (MEC 13.3) were from BD Pharmingen; mouse mAb specific for activated human $\beta_{1}$ integrin (HUTS-4) was from Millipore Sigma; mouse mAb against GAPDH (2D4A7) was from Novus Biologicals; rabbit mAb against actin (D18C11), rabbit mAb against Snail (C15D3), rabbit mAb to Src (36D10), and phosphor-Src (D49G4) were from Cell Signaling Technology; rat mAb anti-F4/80, Alexa-coupled secondary antibodies, and Alexacoupled phalloidins were from Thermo Fisher Scientific; rabbit polyclonal antibodies against fibronectin were from Millipore Sigma; rabbit polyclonal antibodies against $\mathrm{N}$-cadherin were from Thermo Fisher Scientific; rabbit polyclonal antibodies to Twist were from GeneTex; rabbit polyclonal antibodies against vWf were from Agilent; horseradish peroxidase-conjugated secondary antibodies were from BioRad; and PKC inhibitors used were from MilliporeSigma: the $\mathrm{PKC}_{\alpha / \beta}$ inhibitor was N-Myr-FARKGALRQ- $\mathrm{NH}_{2}$, the $\mathrm{PKC}_{\theta / \delta}$ inhibitor was 5-(3,4Dimethoxyphenyl)-4-(1H-indol-5-ylamino)-3pyridinecarbonitrile, and the $\mathrm{PKC}_{\theta}$ inhibitor was Myr-LHQRRGAIKQAKVHHVKC-NH$H_{2}$. ECL reagent was from Roche, RPMI, DMEM/F12, penicillin/streptomycin, and L-glutamine were from the Media Lab (Cleveland Clinic).

\section{cDNA constructs}

EGFP-tagged kindlin-3 was created by cloning full-length kindlin-3 in a frame with EGFP into pEGFP-C2 vector (Clontech) as previously described (Malinin et al, 2009). All indicated mutations of kindlin-3 were introduced into constructs using QuikChange site-directed mutagenesis kits from Agilent Technologies (Santa Clara) and authenticated by DNA sequencing.

\section{Cell culture and transfections}

Human MDA-MB-231 and BT549 BC lines and HEL cells were obtained from the American Type Culture Collection (ATCC) and cultured as per the ATTC instructions. Growth and morphology of the cells were routinely monitored, and they maintained key features consistent with prior descriptions of the lines. Derivative clones of the MDA-MB-231 cells with stable expression of EGFP and EGFP-kindlin-3 fusion proteins were established by nucleofection of EGFP-C2 plasmids expressing either EGFP alone or EGFP-kindlin-3 fusion constructs. Stable and continuous expression of the EGFP derivatives was maintained by growing cells in the presence of neomycin $(1 \mathrm{mg} / \mathrm{ml})$, and enrichment for the EGFP-expressing cells was obtained by FACS. Alterations in MDA-MB-231 and BT549 cell proliferation were determined by counting and comparing the number of viable cells over a period of $5 \mathrm{~d}$ after seeding the same number of cells on $d$. None of the expressed fusion proteins affected proliferation rates during this monitoring period.

\section{CRISPR/Cas9 gene editing-mediated targeting of kindlin-3 in BT549 cells}

LentiCRISPRV2 lentiviral plasmid system (Addgene) was used to knockout kindlin-3 in BT549 BC cells using the protocol described by Cong and Zhang (2015). The human kindlin-3-specific sgRNAs were identified on the basis of two different predictive algorithms (Chopchop; https://chopchop.rc.fas.harvard.edu, and CRISPR Design, http://crispr.mit.edu), and the sgRNAs common to both algorithms were validated against human GECKOv2 sgRNA library. Only sgRNAs found in the GECKOV2 library were selected (Cong \& Zhang, 2015). sgRNA oligos were purchased from Integrated DNA Technologies and subcloned into the lentiCRISPRv2 plasmid (Cong \& Zhang, 2015). Lentivirus production and cell infections were performed as described previously (Taylor et al, 2013a, 2013b).

\section{Tissue and cell immunostaining}

Tumor and lung tissues were collected after 9 or 12 wk after tumor implantation, snap-frozen in optimal cutting temperature medium (Sakura Finetek), and $8-\mu \mathrm{m}$ sections were prepared. Blood vessels were visualized with rat antimouse CD31 followed by goat anti-rat Alexa Fluor 568 conjugate or with rabbit anti-vWF. Tumor sections were also stained with the following antibodies: rabbit antifibronectin and rabbit anti-N-cadherin followed by Alexa-568conjugated goat antirabbit IgG. Stained sections were analyzed using fluorescent imaging microscopy (Leica) and ImageJ software. Positive staining areas were quantified in 10-15 independent fields / section.

HEL cells were stimulated with $800 \mathrm{nM}$ PMA and plated onto fibrinogen-coated $(20 \mu \mathrm{g} / \mathrm{ml})$ glass slides for the times indicated, fixed with $4 \%$ PFA, permeabilized with $0.1 \%$ Triton X-100, blocked in horse serum, and stained with the specified antibodies for $\sim 18 \mathrm{~h}$. BT549 cells were spread on $20 \mu \mathrm{g} / \mathrm{ml}$ of fibronectin and processed as described for HEL cells. Antigen-antibody complexes were detected by staining with Alexa-coupled secondary antibodies for $1 \mathrm{~h}$. Stained cells were visualized with a $40 \times$ or $63 \times 1.4$ oil objectives using a Leica TCS-NT laser scanning confocal microscope (Imaging Core; Cleveland Clinic). Laser intensities were adjusted to eliminate cross-over between channels, and the images were collected using Leica Confocal Software (version 2.5 Build 1227). 


\section{Invasion assays}

For invasion assays, modified Boyden chambers were coated with Matrigel (1:1 dilution; BD Biosciences) and used to compare the invasiveness of MDA-MB-231 cells expressing EGFP alone or EGFPkindlin-3 fusion proteins in response to $10 \%$ serum as described (Sossey-Alaoui et al, 2014). The invading cells were stained with Alexa-488 phalloidin and analyzed using fluorescent imaging microscopy (Leica) and ImageJ software. Cell number was quantified in 10-15 independent fields/chamber.

\section{VEGF ELISA assay}

VEGF secreted into the conditioned medium of MDA-MDB231 cells was quantified using the ELISA development kit and polyclonal rabbit antihuman VEGF from PeproTech as previously described (Sossey-Alaoui et al, 2014).

\section{Flow cytometry and soluble ligand binding}

To assess $\beta 1$ integrin activation, HUTS- 4 binding to the different kindlin-3 transfectants was analyzed by gating only on the EGFPpositive cells. Mean fluorescence intensities (MFI) of mAb HUTS-4 binding were normalized to total $\beta 1$ integrin surface expression measured with mAb 13. Cells $\left(2 \times 10^{5}\right.$ cells) were incubated with HUTS-4 $(20 \mu \mathrm{l})$ four in HBSS buffer containing 0.1\% BSA, $0.5 \mathrm{mM}$ $\mathrm{CaCl}_{2}, \mathrm{MgCl}_{2}$ for $30 \mathrm{~min}$, and then fixed with $1 \%$ PFA for $10 \mathrm{~min}$ in room temperature. After washing, the cells were incubated with R-PE-labeled secondary antibody $(10 \mu \mathrm{g} / \mathrm{ml})$ for $30 \mathrm{~min}$. Antibody binding was analyzed using LSRFortessa flow cytometer and FlowJo software (BD Biosciences).

\section{Development of kindlin-3 phosphoantibodies}

C-LSLQRTGPSGG, C-LSLQRPTGSGG, and C-LSLQRTGSGG peptides were synthetized and purified in Molecular Biotechnology Core of Cleveland Clinic. Peptides were conjugation to KLH with glutaraldehyde. Four mice were injected into the peritoneum with an emulsion containing the antigen and an equal volume of Freund's adjuvant. Complete Freund's adjuvant was used for the first injection, Incomplete Freund's was used for subsequent boosts, and no adjuvant was used for the final injection. Mice were injected at 3-wk intervals. $10 \mathrm{~d}$ after the third injection, the concentration of antibodies specific to each antigen was measured in the serum by ELISA. Spleen cells from the highest titer mouse were fused with SP2/ 0 cells by a standard PEG/DMSO method, and fused cells were selected using HAT media. $14 \mathrm{~d}$ later, supernatants were assayed by ELISA on the specific antigens. Cells from positive wells were expanded for cloning and individual cells producing antibodies were isolated from the mixed culture by the limiting dilution. Antibodies were developed in the Hybridoma Core of Cleveland Clinic. Antibodies were purified from tissue culture supernatants using Pierce Protein A IgG Purification Kit from Thermo Fisher Scientific.

\section{ELISA assay}

$50 \mu \mathrm{l}$ of peptide $(4 \mu \mathrm{g} / \mathrm{ml})$ in coating buffer was added to individual wells of microtiter plates and incubated overnight at $4^{\circ} \mathrm{C}$. The wells were washed three times with $100 \mu \mathrm{l}$ PBS and 0.05\% Tween 20, blocked with $150 \mu$ lof PBS containing $0.4 \%$ BSA, and incubated for $60 \mathrm{~min}$ in $37^{\circ} \mathrm{C}$. Wells were washed three times with $100 \mathrm{ml}$ PBS and $0.05 \%$ Tween $20,50 \mu$ l of diluted antibody was added to each well, and the wells were incubated for $30 \mathrm{~min}$ in $37^{\circ} \mathrm{C}$. After washing, $50 \mu \mathrm{l}$ of secondary antibody was added to each well (rat-antimouse IgG1 from Southern Biotech). Reaction was developed by adding $100 \mu \mathrm{l}$ of o-phenylenediamine dihydrochloride (Millipore Sigma), and incubation was carried out for $15 \mathrm{~min}$. After sufficient color development, the reaction was terminated with $100 \mu \mathrm{l}$ of $5 \mathrm{~N} \mathrm{H}_{2} \mathrm{SO}_{4}$. Absorbance was read at $492 \mathrm{~nm}$.

\section{Platelet isolation}

Platelets were isolated as described previously (Plow \& Ginsberg, 1981) from the blood of healthy volunteers drawn into acid/citrate/ dextrose, $\mathrm{pH} 4.6$, containing $2 \mu \mathrm{M}$ prostaglandin $\mathrm{E}_{1}$. Blood was centrifuged to obtain platelet-rich plasma, which was then further centrifuged, and the platelet pellet was suspended in $\mathrm{Ca}^{2+}$ - and $\mathrm{Mg}^{2+}$ free Tyrode's buffer ( $138 \mathrm{mM} \mathrm{NaCl}, 12 \mathrm{mM} \mathrm{NaHCO}, 0.36 \mathrm{mM} \mathrm{Na}_{2} \mathrm{HPO}_{4}$, $2.9 \mathrm{mM} \mathrm{KCl}, 10 \mathrm{mM}$ Hepes, $0.1 \%$ glucose, $0.1 \%$ bovine serum albumin, $\mathrm{pH}$ 7.1) and gel-filtered through a Sepharose CL-4B (GE Healthcare) column in Tyrode's buffer to obtain the platelet preparations. Platelet counts were determined using a hemocytometer.

\section{Platelet aggregation and kindlin-3 phosphorylation}

Effect of thrombin or PMA on kindlin-3 phosphorylation was examined using a kindlin-3 phosphospecific mAb while monitoring aggregation in an aggregometer (Chrono-log Corporation). Platelets $\left(3 \times 10^{8} / \mathrm{ml}\right)$ were equilibrated at $37^{\circ} \mathrm{C}$ for $5 \mathrm{~min}$. Then, an agonist was added and aggregation was monitored for times indicated at $37^{\circ} \mathrm{C}$ with stirring. The final volume in each cuvette was $500 \mu \mathrm{l}$. Platelets were solubilized in a Laemmli buffer containing $62.5 \mathrm{mM}$ Tris- $\mathrm{HCl}, \mathrm{pH}$ 7.4, 2\% SDS, 5\% 2-mercaptoethanol, and 10\% glycerol and subjected to SDS-PAGE. Proteins were transferred to PVDF, and blots probed with antibodies of interest using 5\% BSA as a blocking agent.

\section{Isolation of mouse megakaryocytes and $\alpha_{11 \mathrm{~b}} \beta_{3}$ activation assays}

Bone marrow cells were harvested from 8- to 9-wk-old WT and kindlin-3 hypomorphic mice (Xu et al, 2014; Meller et al, 2017) by flushing femurs with Catch Buffer (PBS pH 7.4, 2\% BSA, 0.38\% trisodium citrate, DNAse I $(1 \mathrm{U} / \mathrm{ml})$, penicillin/streptomycin $(100 \mathrm{U} / \mathrm{ml})$. Mononuclear cells were isolated by centrifugation over Ficoll Hypaque Premium (1.080 g/ml; GE Healthcare) at $400 \mathrm{~g}$ for $30 \mathrm{~min}$ at $22^{\circ} \mathrm{C}$. Low-density mononuclear cells were cultured for up to $5 \mathrm{~d}$ at a starting density of $1 \times 10^{6} / \mathrm{ml}$ in serum-free IMDM medium supplemented as described (Zauli et al, 1997; Shiraga et al, 1999) in the presence of $50 \mathrm{ng} / \mathrm{ml}$ murine TPO (R\&D Systems) and $10 \mathrm{ng} / \mathrm{ml}$ murine IL-11 and IL-6 (Millipore Sigma). After $5 \mathrm{~d}$ in culture, the cells were treated with lentiviral vectors (Xu et al, 2018) expressing EGFPtagged kindlin-3 (WT), QW/AA, TS/AA, or EGFP only as described. $48 \mathrm{~h}$ 
post-transduction, the cells were either untreated or stimulated with PAR-4 agonist peptide (100 $\mu \mathrm{g} / \mathrm{ml}$; Bachem) for $30 \mathrm{~min}$ at $37^{\circ} \mathrm{C} . \alpha_{\| \mathrm{b}} \beta_{3}$ integrin activation was measured by flow cytometry of EGFP-positive cell populations using $\mathrm{PE}$-labeled $\mathrm{Ab}$ to activation-dependent epitope of CD41/CD61 (clone JON/A) (Emfret Analytics) and rat antimouse total CD41-PerCP/Cy5.5 (BioLegend). The data are expressed as $\%$ activation $=($ MFI JONA $/$ MFI total CD41 $) \times 100$.

\section{Immunoprecipitation}

For antibody-mediated precipitation of endogenous kindlin-3, HEL cells were stimulated with PMA, and the samples were lysed in $50 \mathrm{mM}$ Tris- $\mathrm{HCl}, \mathrm{pH} 7.4,150 \mathrm{mM} \mathrm{NaCl}$ chloride, $1 \% \mathrm{NP}-40$, and $1 \mathrm{mM} \mathrm{CaCl}$, containing protease and phosphatase inhibitors. Lysates were held on ice for $30 \mathrm{~min}$ before centrifugation at $12,000 \mathrm{~g}$ for $15 \mathrm{~min}$. Aliquots of the detergent-soluble material were precleared on $A / G$ protein agarose for $1 \mathrm{~h}$ in $4^{\circ} \mathrm{C}$. The lysates were incubated with $2 \mu \mathrm{l}$ of antibodies or pre-immune serum and protein A/G agarose for $16 \mathrm{~h}$ at $4^{\circ} \mathrm{C}$. Immunoprecipitated proteins were solubilized in Laemmli buffer and analyzed on Western blots with selected antibodies.

\section{Statistical analysis}

Means and standard errors are reported. Statistical analyses using a two-tailed $t$ tests were performed in SigmaPlot (version 11). Differences were considered to be significant with $P<0.05$.

\section{Supplementary Information}

Supplementary Information is available at https://doi.org/10.26508/lsa. 201900594.

\section{Acknowledgements}

This work was supported by National Institute of Health (NIH) grants (P01HL073311 and R01 HL096062) from the Heart, Lung, and Blood Institute to EF Plow. This work used the Leica SP8 confocal microscope that was purchased with funding from NIH Shared Instrumentation Grant 1S100D01997201. We thank Dr Daniel Lindner and Yvonne Parker LRI/Case Cancer Center Tumor Core for their assistance with the animal work.

\section{Author Contributions}

K Bialkowska: conceptualization, software, formal analysis, validation, investigation, methodology, and writing-original draft, review, and editing.

K Sossey-Alaoui: formal analysis, methodology, and writing-review and editing.

E Pluskota: formal analysis, methodology, and writing-review and editing.

L Izem: formal analysis, methodology, and writing-review and editing.

J Qin: writing-review and editing.

EF Plow: conceptualization, supervision, and writing-original draft, review, and editing.

\section{Conflict of Interest Statement}

The authors declare that they have no conflict of interest.

\section{References}

Azorin P, Bonin F, Moukachar A, Ponceau A, Vacher S, Bieche I, Marangoni E, Fuhrmann L, Vincent-Salomon A, Lidereau R, et al (2018) Distinct expression profiles and functions of Kindlins in breast cancer. J Exp Clin Cancer Res 37: 281. doi:10.1186/s13046-018-0955-4

Beck F, Geiger J, Gambaryan S, Solari FA, Dell'Aica M, Loroch S, Mattheij NJ, Mindukshev I, Potz O, Jurk K, et al (2017) Temporal quantitative phosphoproteomics of ADP stimulation reveals novel central nodes in platelet activation and inhibition. Blood 129: e1-e12. doi:10.1182/ blood-2016-05-714048

Bergmeier W, Schulte V, Brockhoff G, Bier U, Zirngibl H, Nieswandt B (2002) Flow cytometric detection of activated mouse integrin alphallbbeta3 with a novel monoclonal antibody. Cytometry 48: 80-86. doi:10.1002/ cyto.10114

Bialkowska K, Byzova TV, Plow EF (2015) Site-specific phosphorylation of kindlin-3 protein regulates its capacity to control cellular responses mediated by integrin alphallbbeta3. J Biol Chem 290: 6226-6242. doi:10.1074/jbc.m114.634436

Bialkowska K, Ma YQ, Bledzka K, Sossey-Alaoui K, Izem L, Zhang X, Malinin N, Qin J, Byzova T, Plow EF (2010) The integrin coactivator kindlin-3 is expressed and functional in a non-hematopoietic cell, the endothelial cell. J Biol Chem 285: 18640-18649. doi:10.1074/ jbc.m109.085746

Bledzka K, Bialkowska K, Sossey-Alaoui K, Vaynberg J, Pluskota E, Qin J, Plow EE (2016) Kindlin-2 directly binds actin and regulates integrin outsidein signaling. J Cell Biol 213: 97-108. doi:10.1083/jcb.201501006

Bledzka K, Liu J, Xu Z, Perera HD, Yadav SP, Bialkowska K, Qin J, Ma YQ, Plow EF (2012) Spatial coordination of kindlin-2 with talin head domain in interaction with integrin beta cytoplasmic tails. J Biol Chem 287: 24585-24594. doi:10.1074/jbc.m111.336743

Boudignon-Proudhon C, Patel PM, Parise LV (1996) Phorbol ester enhances integrin alpha IIb beta 3-dependent adhesion of human erythroleukemic cells to activation-dependent monoclonal antibodies. Blood 87: 968-976. doi:10.1182/ blood.v87.3.968.bloodjournal873968

Buensuceso CS, Obergfell A, Soriani A, Eto K, Kiosses WB, Arias-Salgado EG, Kawakami T, Shattil SJ (2005) Regulation of outside-in signaling in platelets by integrin-associated protein kinase C beta. J Biol Chem 280: 644-653. doi:10.1074/jbc.m410229200

Calderwood DA, Zent R, Grant R, Rees DJ, Hynes RO, Ginsberg MH (1999) The Talin head domain binds to integrin beta subunit cytoplasmic tails and regulates integrin activation. J Biol Chem 274: 28071-28074. doi:10.1074/jbc.274.40.28071

Castagna M, Takai Y, Kaibuchi K, Sano K, Kikkawa U, Nishizuka Y (1982) Direct activation of calcium-activated, phospholipid-dependent protein kinase by tumor-promoting phorbol esters. J Biol Chem 257: 7847-7851.

Cifuni SM, Wagner DD, Bergmeier W (2008) CalDAG-GEFI and protein kinase C represent alternative pathways leading to activation of integrin alphallbbeta3 in platelets. Blood 112: 1696-1703. doi:10.1182/blood2008-02-139733

Cole DC, Asselin M, Brennan A, Czerwinski R, Ellingboe JW, Fitz L, Greco R, Huang X, Joseph-McCarthy D, Kelly MF, et al (2008) Identification, characterization and initial hit-to-lead optimization of a series of 4-arylamino-3-pyridinecarbonitrile as protein kinase $C$ theta (PKCtheta) inhibitors. J Med Chem 51: 5958-5963. doi:10.1021/ jm800214a 
Cong L, Zhang F (2015) Genome engineering using CRISPR-Cas9 system. Methods Mol Biol 1239: 197-217. doi:10.1007/978-1-4939-1862-1_10

Djaafri I, Khayati F, Menashi S, Tost J, Podgorniak MP, Sadoux A, Daunay A, Teixeira L, Soulier J, Idbaih A, et al (2014) A novel tumor suppressor function of Kindlin-3 in solid cancer. Oncotarget 5: 8970-8985. doi:10.18632/oncotarget.2125

Dowling JJ, Gibbs E, Russell M, Goldman D, Minarcik J, Golden JA, Feldman EL (2008) Kindlin-2 is an essential component of intercalated discs and is required for vertebrate cardiac structure and function. Circ Res 102: 423-431. doi:10.1161/circresaha.107.161489

Feng C, Li YF, Yau YH, Lee HS, Tang XY, Xue ZH, Zhou YC, Lim WM, Cornvik TC, Ruedl C, et al (2012) Kindlin-3 mediates integrin alphaLbeta2 outside-in signaling, and it interacts with scaffold protein receptor for activated-C kinase 1 (RACK1). J Biol Chem 287: 10714-10726. doi:10.1074/jbc.m111.299594

Feng C, Wee WK, Chen H, Ong LT, Qu J, Tan HF, Tan SM (2017) Expression of kindlin-3 in melanoma cells impedes cell migration and metastasis. Cell Adh Migr 11: 419-433. doi:10.1080/19336918.2016.1243645

Gao J, Huang M, Lai J, Mao K, Sun P, Cao Z, Hu Y, Zhang Y, Schulte ML, Jin C, et al (2017) Kindlin supports platelet integrin alphallbbeta3 activation by interacting with paxillin. J Cell Sci 130: 3764-3775. doi:10.1242/jcs.205641

Garcia-Alvarez B, de Pereda JM, Calderwood DA, Ulmer TS, Critchley D, Campbell ID, Ginsberg MH, Liddington RC (2003) Structural determinants of integrin recognition by talin. Mol Cell 11: 49-58. doi:10.1016/s1097-2765(02)00823-7

Goksoy E, Ma YQ, Wang X, Kong X, Perera D, Plow EF, Qin J (2008) Structural basis for the autoinhibition of talin in regulating integrin activation. Mol Cell 31: 124-133. doi:10.1016/j.molcel.2008.06.011

Gough RE, Goult BT (2018) The tale of two talins: Two isoforms to fine-tune integrin signalling. FEBS Lett 592: 2108-2125. doi:10.1002/18733468.13081

Hunter T (1987) A tail of two src's: Mutatis mutandis. Cell 49: 1-4. doi:10.1016/ 0092-8674(87)90745-8

Jarvinen M, Ylanne J, Vartio T, Virtanen I (1987) Tumor promoter and fibronectin induce actin stress fibers and focal adhesion sites in spreading human erythroleukemia (HEL) cells. Eur J Cell Biol 44: 238-246.

Jobard F, Bouadjar B, Caux F, Hadj-Rabia S, Has C, Matsuda F, Weissenbach J, Lathrop M, Prud'homme JF, Fischer I (2003) Identification of mutations in a new gene encoding a FERM family protein with a pleckstrin homology domain in Kindler syndrome. Hum Mol Genet 12: 925-935. doi:10.1093/hmg/ddg097

Kikkawa U, Takai Y, Tanaka Y, Miyake R, Nishizuka Y (1983) Protein kinase C as a possible receptor protein of tumor-promoting phorbol esters. I Biol Chem 258: 11442-11445.

Kim DE, Chivian D, Baker D (2004) Protein structure prediction and analysis using the Robetta server. Nucleic Acids Res 32: W526-W531. doi:10.1093/nar/gkh404

Klapholz B, Brown NH (2017) Talin: The master of integrin adhesions. J Cell Sci 130: 2435-2446. doi:10.1242/jcs.190991

Klapproth S, Bromberger T, Turk C, Kruger M, Moser M (2019) A kindlin-3leupaxin-paxillin signaling pathway regulates podosome stability. J Cell Biol 218: 3436-3454. doi:10.1083/jcb.201903109

Klapproth S, Moretti FA, Zeiler M, Ruppert R, Breithaupt U, Mueller S, Haas R, Mann M, Sperandio M, Fassler R, et al (2015) Minimal amounts of kindlin-3 suffice for basal platelet and leukocyte functions in mice. Blood 126: 2592-2600. doi:10.1182/blood-2015-04-639310

Kuijpers TW, van de Vijver E, Weterman MA, de Boer M, Tool AT, van den Berg TK, Moser M, Jakobs ME, Seeger K, et al (2009) LAD-1/variant syndrome is caused by mutations in FERMT3. Blood 113: 4740-4746. doi:10.1182/ blood-2008-10-182154

Li H, Deng Y, Sun K, Yang H, Liu J, Wang M, Zhang Z, Lin J, Wu C, Wei Z, et al (2017) Structural basis of kindlin-mediated integrin recognition and activation. Proc Natl Acad Sci U S A 114: 9349-9354. doi:10.1073/ pnas.1703064114

Liao Z, Kato H, Pandey M, Cantor JM, Ablooglu AJ, Ginsberg MH, Shattil SJ (2015) Interaction of kindlin-2 with integrin beta3 promotes outside-in signaling responses by the alphaVbeta3 vitronectin receptor. Blood 125: 1995-2004. doi:10.1182/blood-2014-09-603035

Liu Z, Lu D, Wang X, Wan J, Liu C, Zhang H (2015) Kindlin-2 phosphorylation by Src at Y193 enhances Src activity and is involved in Migfilin recruitment to the focal adhesions. FEBS Lett 589: 2001-2010. doi:10.1016/j.febslet.2015.05.038

Lu C, Cui C, Liu B, Zou S, Song H, Tian H, Zhao J, Li Y (2017) FERMT3 contributes to glioblastoma cell proliferation and chemoresistance to temozolomide through integrin mediated Wnt signaling. Neurosci Lett 657: 77-83. doi:10.1016/j.neulet.2017.07.057

Luque A, Gomez M, Puzon W, Takada Y, Sanchez-Madrid F, Cabanas C (1996) Activated conformations of very late activation integrins detected by a group of antibodies (HUTS) specific for a novel regulatory region (355-425) of the common $\beta 1$ chain. J Biol Chem 271: 11067-11075. doi:10.1074/jbc.271.19.11067

Ma YQ, Qin J, Plow EF (2007) Platelet integrin alpha(IIb)beta(3): Activation mechanisms. J Thromb Haemost 5: 1345-1352. doi:10.1111/j.15387836.2007.02537.x

Ma YQ, Qin J, Wu C, Plow EF (2008) Kindlin-2 (Mig-2): A co-activator of beta3 integrins. J Cell Biol 181: 439-446. doi:10.1083/jcb.200710196

Malinin NL, Zhang L, Choi J, Ciocea A, Razorenova O, Ma YQ, Podrez EA, Tosi M, Lennon DP, Caplin Al, et al (2009) A point mutation in kindlin-3 ablates activation of three integrin subfamilies in humans. Nat Med 15: 313-318. doi:10.1038/nm.1917

Marguerie GA, Plow EF, Edgington TS (1979) Human platelets possess an inducible and saturable receptor specific for fibrinogen. J Biol Chem 254: 5357-5363.

Meller J, Chen ZH, Dudiki T, Cull RM, Murtazina R, Bal SK, Pluskota E, Stefl S, Plow EF, Trapp BD, et al (2017) Integrin-Kindlin3 requirements for microglial motility in vivo are distinct from those for macrophages. JCI Insight 2: 93002. doi:10.1172/jci.insight.93002

Meller J, Malinin NL, Panigrahi S, Kerr BA, Patil A, Ma Y, Venkateswaran L, Rogozin IB, Mohandas N, Ehlayel MS, et al (2012) Novel aspects of Kindlin-3 function in humans based on a new case of leukocyte adhesion deficiency III. J Thromb Haemost 10: 1397-1408. doi:10.1111/ j.1538-7836.2012.04768.x

Mironchik Y, Winnard PT Jr, Vesuna F, Kato Y, Wildes F, Pathak AP, Kominsky S, Artemov D, Bhujwalla Z, Van DP, et al (2005) Twist overexpression induces in vivo angiogenesis and correlates with chromosomal instability in breast cancer. Cancer Res 65: 10801-10809. doi:10.1158/ 0008-5472.can-05-0712

Montanez E, Ussar S, Schifferer M, Bosl M, Zent R, Moser M, Fassler R (2008) Kindlin-2 controls bidirectional signaling of integrins. Genes Dev 22: 1325-1330. doi:10.1101/gad.469408

Moser M, Nieswandt B, Ussar S, Pozgajova M, Fassler R (2008) Kindlin-3 is essential for integrin activation and platelet aggregation. Nat Med 14 325-330. doi:10.1038/nm1722

Osada S, Mizuno K, Saido TC, Suzuki K, Kuroki T, Ohno S (1992) A new member of the protein kinase C family, nPKC theta, predominantly expressed in skeletal muscle. Mol Cell Biol 12: 3930-3938. doi:10.1128/mcb.12.9.3930

Plow EF, Das M, Bialkowska K, Sossey-Alaoui K (2016) Of kindlins and cancer. Discoveries (Craiova) 4: e59. doi:10.15190/d.2016.6

Plow EF, Ginsberg MH (1981) Specific and saturable binding of plasma fibronectin to thrombin-stimulated human platelets. J Biol Chem 256: 9477-9482.

Qin J, Vinogradova O, Plow EF (2004) Integrin bidirectional signaling: A molecular view. PLoS Biol 2: 0726-0729. doi:10.1371/ journal.pbio.0020169 
Qu H, Tu Y, Guan JL, Xiao G, Wu C (2014) Kindlin-2 tyrosine phosphorylation and interaction with Src serve as a regulatable switch in the integrin outside-in signaling circuit. J Biol Chem 289: 31001-31013. doi:10.1074/ jbc.m114.580811

Qu J, Ero R, Feng C, Ong LT, Tan HF, Lee HS, Ismail MH, Bu WT, Nama S, Sampath $P$, et al (2015) Kindlin-3 interacts with the ribosome and regulates CMyc expression required for proliferation of chronic myeloid leukemia cells. Sci Rep 5: 18491. doi:10.1038/srep18491

Resjo S, Oknianska A, Zolnierowicz S, Manganiello V, Degerman E (1999) Phosphorylation and activation of phosphodiesterase type 3B (PDE3B) in adipocytes in response to serine/threonine phosphatase inhibitors: Deactivation of PDE3B in vitro by protein phosphatase type 2A. Biochem / 341: 839-845. doi:10.1042/0264-6021:3410839

Shattil SJ (2005) Integrins and Src: Dynamic duo of adhesion signaling. Trends Cell Biol 15: 399-403. doi:10.1016/j.tcb.2005.06.005

Shi X, Ma YQ, Tu Y, Chen K, Wu S, Fukuda K, Qin J, Plow EF, Wu C (2007) The MIG$2 /$ integrin interaction strengthens cell-matrix adhesion and modulates cell motility. J Biol Chem 282: 20455-20466. doi:10.1074/ jbc.m611680200

Shiraga M, Ritchie A, Aidoudi S, Baron V, Wilcox D, White G, Ybarrondo B, Murphy G, Leavitt A, Shattil S (1999) Primary megakaryocytes reveal a role for transcription factor NF-E2 in integrin alpha IIb beta 3 signaling. J Cell Biol 147: 1419-1430. doi:10.1083/jcb.147.7.1419

Siegel DH, Ashton GH, Penagos HG, Lee JV, Feiler HS, Wilhelmsen KC, South AP, Smith FJ, Prescott AR, Wessagowit V, et al (2003) Loss of kindlin-1, a human homolog of the Caenorhabditis elegans actin-extracellularmatrix linker protein UNC-112, causes Kindler syndrome. Am J Hum Genet 73: 174-187. doi:10.1086/376609

Soriani A, Moran B, de Virgilio M, Kawakami T, Altman A, Lowell C, Eto K, Shattil S) (2006) A role for PKCtheta in outside-in alpha(IIb)beta3 signaling. J Thromb Haemost 4: 648-655. doi:10.1111/j.1538-7836.2006.01806.x

Sossey-Alaoui K, Pluskota E, Davuluri G, Bialkowska K, Das M, Szpak D, Lindner DJ, Downs-Kelly E, Thompson CL, Plow EF (2014) Kindlin-3 enhances breast cancer progression and metastasis by activating Twist-mediated angiogenesis. FASEB / 28: 2260-2271. doi:10.1096/fj.13-244004

Sun Z, Costell M, Fassler R (2019) Integrin activation by talin, kindlin and mechanical forces. Nat Cell Biol 21: 25-31. doi:10.1038/s41556-0180234-9

Svensson L, Howarth K, McDowall A, Patzak I, Evans R, Ussar S, Moser M, Metin A, Fried M, Tomlinson I, et al (2009) Leukocyte adhesion deficiency-III is caused by mutations in KINDLIN3 affecting integrin activation. Nat Med 15: 306-312. doi:10.1038/nm.1931

Tadokoro S, Shattil SJ, Eto K, Tai V, Liddington RC, de Pereda JM, Ginsberg MH, Calderwood DA (2003) Talin binding to integrin $\beta$ tails: A final common step in integrin activation. Science 302: 103-106. doi:10.1126/ science. 1086652

Taylor MA, Davuluri G, Parvani JG, Schiemann BJ, Wendt MK, Plow EF, Schiemann WP, Sossey-Alaoui K (2013a) Upregulated WAVE3 expression is essential for TGF-beta-mediated EMT and metastasis of triple-negative breast cancer cells. Breast Cancer Res Treat 142: 341-353. doi:10.1007/s10549-013-2753-1

Taylor MA, Sossey-Alaoui K, Thompson CL, Danielpour D, Schiemann WP (2013b) TGF-beta upregulates miR-181a expression to promote breast cancer metastasis. J Clin Invest 123: 150-163. doi:10.1172/jci64946

Tu Y, Wu S, Shi X, Chen K, Wu C (2003) Migfilin and Mig-2 link focal adhesions to filamin and the actin cytoskeleton and function in cell shape modulation. Cell 113: 37-47. doi:10.1016/s0092-8674(03)00163-6

Ussar S, Wang HV, Linder S, Fassler R, Moser M (2006) The kindlins: Subcellular localization and expression during murine development. Exp Cell Res 312: 3142-3151. doi:10.1016/j.yexcr.2006.06.030

Vilahur G, Gutierrez M, Arzanauskaite M, Mendieta G, Ben-Aicha S, Badimon L (2018) Intracellular platelet signalling as a target for drug development. Vascul Pharmacol 111: 22-25. doi:10.1016/ j.vph.2018.08.007

Vinogradova O, Velyvis A, Velyviene A, Hu B, Haas TA, Plow EF, Qin J (2002) A structural mechanism of integrin $\alpha$ llb $\beta 3$ "inside-out" activation as regulated by its cytoplasmic face. Cell 110: 587-597. doi:10.1016/s00928674(02)00906-6

Ward NE, O'Brian CA (1993) Inhibition of protein kinase C by N-myristoylated peptide substrate analogs. Biochemistry 32: 11903-11909. doi:10.1021/ bi00095a020

Wu WB, Zhang Q, Li Y, Shan SL, Li XY, Tian Z, Tang KJ, Wang M, Rao Q, Mi YC (2012) Expression of Kindlins and angiopoietins in acute myeloid leukemia. Zhongguo Shi Yan Xue Ye Xue Za Zhi 20: 7-11.

Xu Z, Chen X, Zhi H, Gao J, Bialkowska K, Byzova TV, Pluskota E, White GC, Liu J, Plow EF, et al (2014) Direct interaction of kindlin-3 with integrin alphallbbeta3 in platelets is required for supporting arterial thrombosis in mice. Arterioscler Thromb Vasc Biol 9: 1961-1967. doi:10.1161/atvbaha.114.303851

Xu Z, Ni B, Cao Z, Zielonka J, Gao J, Chen F, Kalyanaraman B, White GC, Ma YQ (2018) Kindlin-3 negatively regulates the release of neutrophil extracellular traps. J Leukoc Biol 104: 597-602. doi:10.1002/jlb.3ab0118$005 r$

Xue ZH, Feng C, Liu WL, Tan SM (2013) A role of kindlin-3 in integrin alphaMbeta2 outside-in signaling and the Syk-Vav1-Rac1/Cdc42 signaling axis. PLoS One 8: e56911. doi:10.1371/journal.pone.0056911

Yacoub D, Theoret JF, Villeneuve L, Abou-Saleh H, Mourad W, Allen BG, Merhi Y (2006) Essential role of protein kinase C delta in platelet signaling, alpha IIb beta 3 activation, and thromboxane A2 release. I Biol Chem 281: 30024-30035. doi:10.1074/jbc.m604504200

Ye F, Petrich BG, Anekal P, Lefort CT, Kasirer-Friede A, Shattil SJ, Ruppert R, Moser M, Fassler R, Ginsberg MH (2013) The mechanism of kindlinmediated activation of integrin alphallbbeta3. Curr Biol 23: 2288-2295. doi:10.1016/j.cub.2013.09.050

Ylanne J, Cheresh DA, Virtanen I (1990) Localization of beta 1, beta 3, alpha 5 , alpha $\mathrm{V}$, and alpha IIb subunits of the integrin family in spreading human erythroleukemia cells. Blood 76: 570-577. doi:10.1182/ blood.v76.3.570.bloodjournal763570

Ylanne J, Hormia M, Jarvinen M, Vartio T, Virtanen I (1988) Platelet glycoprotein IIb/IIla complex in cultured cells. Localization in focal adhesion sites in spreading HEL cells. Blood 72: 1478-1486. doi:10.1182/ blood.v72.5.1478.bloodjournal7251478

Zauli G, Bassini A, Vitale M, Gibellini D, Celeghini C, Caramelli E, Pierpaoli S, Guidotti L, Capitani S (1997) Thrombopoietin enhances the alpha IIb beta 3-dependent adhesion of megakaryocytic cells to fibrinogen or fibronectin through PI 3 kinase. Blood 89: 883-895. doi:10.1182/ blood.v89.3.883

Zhang Z, Mu Y, Veevers J, Peter AK, Manso AM, Bradford WH, Dalton ND, Peterson KL, Knowlton KU, Ross RS, et al (2016) Postnatal loss of kindlin-2 leads to progressive heart failure. Circ Heart Fail 9: e003129. doi:10.1161/circheartfailure.116.003129

Zhao Y, Malinin NL, Meller J, Ma Y, West XZ, Bledzka K, Qin J, Podrez EA, Byzova TV (2012) Regulation of cell adhesion and migration by Kindlin-3 cleavage by calpain. J Biol Chem 287: 40012-40020. doi:10.1074/ jbc.m112.380469

Zimman A, Titz B, Komisopoulou E, Biswas S, Graeber TG, Podrez EA (2014) Phosphoproteomic analysis of platelets activated by pro-thrombotic oxidized phospholipids and thrombin. PLoS One 9: e84488. doi:10.1371/journal.pone.0084488

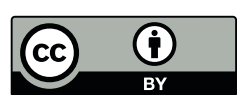

License: This article is available under a Creative Commons License (Attribution 4.0 International, as described at https://creativecommons.org/ licenses/by/4.0/). 